\title{
2016 Monsoon convection and its place in the large-scale circulation using doppler radars
}

Article

Published Version

Creative Commons: Attribution 4.0 (CC-BY)

Open access

Doyle, A. J., Stein, T. H. M. ORCID: https://orcid.org/00000002-9215-5397 and Turner, A. G. ORCID:

https://orcid.org/0000-0002-0642-6876 (2021) 2016 Monsoon convection and its place in the large-scale circulation using doppler radars. Journal of Geophysical Research:

Atmospheres, 126 (22). e2021JD035496. ISSN 2169-8996 doi:

https://doi.org/10.1029/2021JD035496 Available at https://centaur.reading.ac.uk/101167/

It is advisable to refer to the publisher's version if you intend to cite from the work. See Guidance on citing.

To link to this article DOI: http://dx.doi.org/10.1029/2021JD035496

Publisher: American Geophysical Union

All outputs in CentAUR are protected by Intellectual Property Rights law, including copyright law. Copyright and IPR is retained by the creators or other copyright holders. Terms and conditions for use of this material are defined in the End User Agreement. 


\section{CentAUR}

Central Archive at the University of Reading

Reading's research outputs online 


\section{JGR Atmospheres}

\section{RESEARCH ARTICLE \\ 10.1029/2021JD035496}

Key Points:

- Indian Doppler Weather radars are used to analyze cell-top height (CTH) during the 2016 monsoon season

- CTH exhibits clear diurnal and intraseasonal variation

- CTH varies by region and is affected by local features and the wider monsoon circulation

Supporting Information:

Supporting Information may be found in the online version of this article.

Correspondence to:

A. J. Doyle,

a.j.doyle@pgr.reading.ac.uk

\section{Citation:}

Doyle, A. J., Stein, T. H. M., \& Turner, A. G. (2021). 2016 monsoon convection and its place in the large-scale circulation using Doppler radars. Journal of Geophysical Research: Atmospheres, 126, e2021JD035496. https://doi.org/10.1029/2021JD035496

Received 9 JUL 2021

Accepted 29 OCT 2021 (c) 2021. The Authors.

This is an open access article under the terms of the Creative Commons Attribution License, which permits use, distribution and reproduction in any medium, provided the original work is properly cited.

\section{Monsoon Convection and Its Place in the Large- Scale Circulation Using Doppler Radars}

\author{
A. J. Doyle ${ }^{1}\left(\mathbb{D}\right.$, T. H. M. Stein ${ }^{1}\left(\mathbb{1}\right.$, and A. G. Turner ${ }^{1,2} \mathbb{(}$ \\ ${ }^{1}$ Department of Meteorology, University of Reading, Reading, UK, ${ }^{2}$ National Centre for Atmospheric Science, \\ University of Reading, Reading, UK
}

\begin{abstract}
Convective cloud development during the Indian monsoon helps moisten the atmospheric environment and drive the monsoon trough northwards each year, bringing a large amount of India's annual rainfall. Therefore, an increased understanding of how monsoon convection develops from observations will help inform model development. In this study, 139 days of India Meteorological Department Doppler weather radar data is analyzed for seven sites across India during the 2016 monsoon season. Convective cell-top heights (CTHs) are objectively identified through the season, and compared with near-surface (at $2 \mathrm{~km}$ height) reflectivity. These variables are analyzed over three time scales of variability during the monsoon: monsoon progression on a month-by-month basis, active-break periods and the diurnal cycle. We find a modal maximum in CTH around 6-8 km for all sites. Cell-averaged reflectivity increases with $\mathrm{CTH}$, at first sharply, then less sharply above the freezing level. Bhopal and Mumbai exhibit lower CTH for monsoon break periods compared to active periods. A clear diurnal cycle in $\mathrm{CTH}$ is seen at all sites except Mumbai. For south-eastern India, the phase of the diurnal cycle depends on whether the surface is land or ocean, with the frequency of oceanic cells typically exhibiting an earlier morning peak compared to land, consistent with the diurnal cycle of precipitation. Our findings confirm that Indian monsoon convective regimes are partly regulated by the large-scale synoptic environment within which they are embedded. This demonstrates the excellent potential for weather radars to improve understanding of convection in tropical regions.
\end{abstract}

\section{Introduction}

The Indian summer monsoon (ISM) is responsible for one of the largest modes of seasonal variability in wind direction and precipitation seen worldwide, and supplies more than $80 \%$ of India's annual rainfall during the Boreal summer months of June to September (Turner et al., 2020). This fact, along with the vast, growing population across South Asia whose livelihoods depend upon monsoon rains, makes it one of the most active areas of research in the atmospheric sciences. The ISM is a complex phenomenon, exhibiting substantial variability on intraseasonal and interannual time scales (e.g., Krishnamurti \& Bhalme, 1976), and monsoon forecasts remain a challenge as a result of this complexity. S. A. Rao et al. (2019) raised three areas of improvement required in numerical weather prediction (NWP) models for improved ISM forecasts: resolution, physics, and ocean coupling. Whilst substantial improvements have been made in recent years, meaningful forecast skill exists only out to four days (Durai \& Roy Bhowmik, 2014; S. A. Rao et al., 2019; Turner et al., 2011). The representation of monsoon clouds in NWP models is one of the most challenging physical aspects of the ISM due to complex and numerous sub-gridscale processes (Willetts et al., 2017). General circulation models (GCMs) used for forecasting have resolutions too large to explicitly capture convective processes, a crucial component of the monsoon. Errors due to parametrization of deep convection in GCMs are quick to grow over time (e.g., Martin et al., 2010). A more detailed view of the monsoon circulation and underlying processes from observations is necessary to better comprehend the intimate coupling between the land surface, boundary layer, and cloud development (Turner et al., 2020). In this vein, we present here an observation-driven analysis of the ISM's distinctive cloud regimes in relation to the large-scale environment.

On average, the monsoon arrives at the tip of south-eastern India on June 1; however, the monsoon onset does not necessarily fall on the same date each year. The leading edge of the monsoon then propagates gradually northwards and westwards, typically reaching the north-west of the country and neighboring Pakistan by mid-July. By September, the monsoon weakens and withdraws gradually from north-western regions, 
moving back south-east. Developing convection over India during early Boreal summer is tied to the progression of the ISM (Menon et al., 2018; Parker et al., 2016). Parker et al. (2016) found that during the early stages of the monsoon at a given location, convection is typically shallow in nature, with moist tropical air increasing the relative humidity near the surface. However, this moisture is initially confined to the lower levels, with any convection vertically capped as a result. This is attributed to a mid-level wedge of dry air at approximately $600 \mathrm{hPa}$, near the freezing level, with winds originating from the desert north-west (Parker et al., 2016). However, moisture starts to penetrate at this level from below with the arrival of early monsoon convection (Menon et al., 2018). Johnson et al. (1996) suggested the increase in moisture near the freezing level in the tropics is likely associated with the melting of ice precipitation. Menon et al. (2018) postulated that due to a mix of surface moistening and atmospheric moistening through additional convection, this moisture then propagates toward the surface, driving the monsoon forwards, perpendicular to the prevailing low-level winds. Furthermore, the advance of the tropical low-level circulation against the retreating dry mid-level north-westerlies as described above is not a steady process (Volonté et al., 2020) and exhibits significant variation on several spatiotemporal scales. Therefore, an enhanced understanding of monsoon cloud development in relation to the large-scale environment that it is embedded within is needed.

Large-scale variability in fields such as temperature, winds, and moisture content all directly affect cloud development. This study will explore cloud regimes and the large-scale environment in relation to three time scales of variability that play a primary role in the ISM. First, monsoon propagation from the southeast to the north of India each year (and its retreat again later in the Boreal summer) is non-steady (Volonté et al., 2020) with substantial interannual variability in arrival times. Therefore, we investigate individual months during the monsoon season from May to September 2016, in order to represent large-scale variability associated with monsoon progression, the peak monsoon, and monsoon withdrawal. Second, systematic variation in convection exists as a result of active and break periods (Krishnamurti \& Bhalme, 1976; Rajeevan et al., 2010), a key component of intraseasonal variability during the ISM. These occur as a manifestation of fluctuations in the Boreal summer intraseasonal oscillation, the northward movement of clouds and convection from the equator to the Indian monsoon region (e.g., Jiang et al., 2004), varying on 30-60 days time scales. Models have been found to lack sufficient variability on intraseasonal time scales over both land and ocean (Martin et al., 2017). Third, monsoon clouds typically exhibit a strong signal on diurnal time scales associated with the solar cycle and heating of the surface (Yang \& Slingo, 2001). However, the diurnal cycle is poorly modeled in the tropics, leading to underestimates in daily mean rainfall (Martin et al., 2017). Currently, there is limited understanding of the main drivers of monsoon convection in different locations, and the relative importance of different factors such as local orography, proximity to the coast, prevailing wind direction, amongst others. Evidently, more observations of monsoon convection are required in order to better understand these relationships.

To observe monsoon storms here, we will use data from a network of operational ground-based Doppler weather radars, managed by the India Meteorological Department (IMD). Similar studies have been performed in the past on radars in the tropics. V. V. Kumar et al. (2013) analyzed convective cloud top height, objectively defined using the C-band polarimetric (CPOL) research radar in Darwin, northern Australia. They related four discrete convective cumulus modes to rainfall events, in an effort to understand what pattern of cloud structures and their temporal progression correlates to the most rainfall. This showed that cloud top height can be used as a robust proxy for convective cell development, and using cloud top height statistically in this manner forms the basis of the present study. In recent years, the IMD Doppler radars have been used increasingly for ISM cloud research. Sindhu and Bhat (2018) analyzed the dynamics and microphysics of monsoonal MCSs using four IMD operational S-band radars, chosen to represent four different climate regions. They also used storm area and height to understand the temporal progression of storms. Following this, Sindhu and Bhat (2019) then looked at monsoon storm statistics and the robustness of radar-derived precipitation estimates using an IMD C-band radar at New Delhi. They subset storms into less intense and more intense categories, and found a positive relationship between maximum echo-top height (ETH) and precipitation amount. However, this relationship was found to be weaker for the less intense storms. Additionally, Utsav et al. (2017) used an X-band radar in the Western Ghats to analyze statistical patterns in convection, and they went on to examine variability in convection as seen by the radar between monsoon active and break periods (Utsav et al., 2019). Here, we build on these studies by comprehensively 
analyzing statistics of cloud height across multiple sites for an entire season, allowing a direct comparison of monsoon cloud regimes in different climate regions.

The IMD radar network is a relatively recent development. Prior understanding of monsoon convection has been driven by use of spaceborne radars aboard the Tropical Rainfall Measurement Mission (TRMM), and its successor (Global Precipitation Measurement, GPM). Romatschke and Houze (2011) focused specifically on the South Asian monsoon, and found the Western Ghats and north-eastern India to exhibit the most persistent convection during the monsoon season. Studies using TRMM can also observe regions that are difficult to access with radars (e.g., the Himalayas; Houze et al., 2007). Despite the infrequent overpasses of TRMM in any particular gridbox, many years of data have also allowed an analysis of the impact of monsoon progression and the diurnal cycle on convection in a regional sense across India (Qie et al., 2014; Romatschke et al., 2010). They found a diurnal maximum in convection during the afternoon and evening over land with a weaker maximum around midday over the ocean. More recently, Shige and Kummerow (2016) studied precipitation-top heights (PTHs) over the Western Ghats region during the ISM and related variation in PTH to low-level static stability. The ground-based radar data from IMD offer several key advantages for the analysis of convection. Compared to spaceborne precipitation radars, ground-based weather radars have superior horizontal resolution and time-continuous measurements, allowing a robust study of smallscale and large-scale monsoon convection, its diurnal cycle, and its seasonal progression across just one year with no spatial sampling bias. The analysis of 2016 in isolation is particularly advantageous as it allows for model evaluation in future, as well as a direct comparison to other work from the INCOMPASS field campaign during that year (Interaction of Convective Organisation with Monsoon Precipitation, Atmosphere, Surface and Sea; Turner et al., 2020). Furthermore, as operational weather radars are becoming increasingly prevalent across tropical regions (Heistermann et al., 2013), the use of radar data in this manner can be expanded to additional locations and years as more data becomes available. Therefore, the proven ability to robustly measure the morphology of clouds and convection using radars is very advantageous to the scientific community.

The overarching aim for this study is to find the spatiotemporal characteristics of convective storms across India during the monsoon season in 2016, which coincides with the period of radar data available to us (May 15 to September 30, 2016). The 2016 season is considered a representative year for analysis (June-September all-India rainfall was $97 \%$ of the long-term average). To summarize our approach, local radar-derived fields of cell-top height $(\mathrm{CTH})$ and near-surface reflectivity are calculated for the seven radars across the entire 2016 monsoon season and statistically analyzed. Patterns in these cells are interpreted over major time scales of variability during the ISM, encompassing the seasonal cycle, active and break events and the diurnal cycle in 2016. Finally, these patterns are related to the large-scale monsoon circulation, in order to assess large-scale patterns of cloud development.

The paper is structured as follows: Section 2 explains in detail how the radars are used to calculate CTH and describes any auxiliary datasets used; Section 3 presents the season-average cell statistics in the context of the large-scale environment; Section 4 assesses cell patterns during 2016 active and break periods; Section 5 examines the diurnal cycle in cell activity at each location, and investigates how it compares between land and ocean, and how it is modulated by monsoon progression and active-break spells through the season. Finally, the main conclusions of this study and key areas requiring future investigation are presented in Section 6.

\section{Data and Methods}

In the following section, we introduce the radar data, first detailing the procedure toward analyzing radar reflectivity on discrete vertical levels. Next, objective definitions for ETH and CTH are given. Additional relevant methods and datasets are specified in Section 2.3.

\subsection{Radar Data}

This study makes use of 139 days of reflectivity data (May 15 to September 30, 2016) from seven Indian Doppler Weather radars (see Figure 1a). These seven radars are part of a wider network managed by the IMD, and are chosen for analysis as they are all S-band (approx. $10 \mathrm{~cm}$ wavelength), are robustly calibrated 

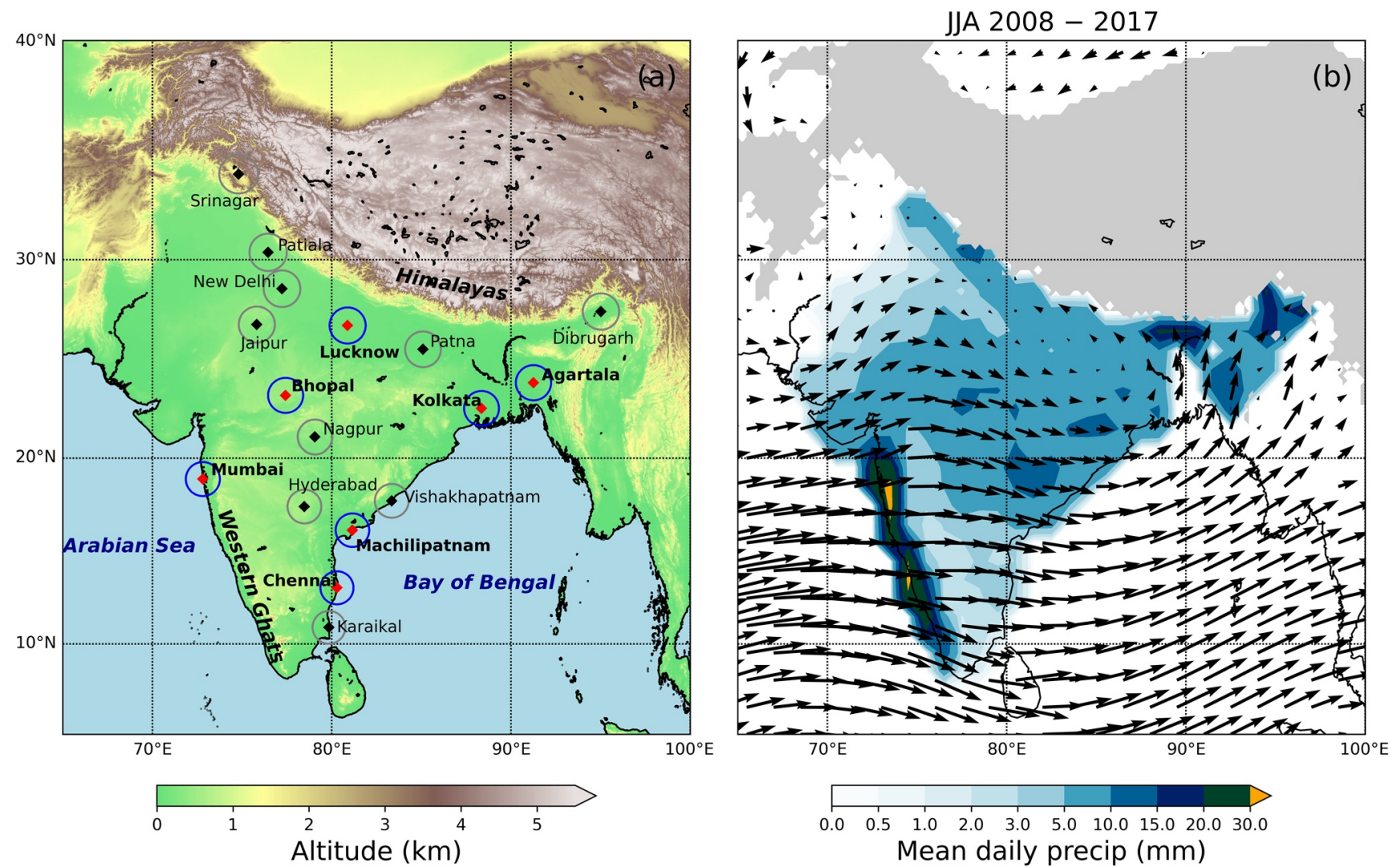

Figure 1. (a) Topographical map of India and surrounding regions, with some major features labeled. Also shown is the network of 17 Indian Meteorological Department Doppler weather radars made available to INCOMPASS, with diamond markers, and rings denoting $100 \mathrm{~km}$ range from the radar. The blue rings (with bold labels and red markers) are the seven radars used in this study. The network has since been expanded further. (b) Recent climatological (2008-2017) precipitation (India only) and $850 \mathrm{hPa}$ winds from India Meteorological Department gridded data and ERA5 respectively. Regions above $1.5 \mathrm{~km}$ in altitude are shaded gray.

(see below) and represent four distinct climate regions with different monsoon rainfall climatology and arrival dates. The south-east sites (Chennai and Machilipatnam) represent coastal India, and are outside the core monsoon circulation. Mumbai in western India represents the west coast and Western Ghats region. Northern India (Bhopal and Lucknow) represents inland regions within the core monsoon circulation. North-eastern India (Agartala and Kolkata) is a near-coastal region where the monsoon winds typically begin to curve back to the north (Figure 1b). Two radars per region were identified for analysis if possible, to allow comparison within each region. However, Mumbai was the only radar with data available on the west coast.

Each radar volume scan consists of 10 elevation angles from $0.2^{\circ}$ to $21^{\circ}$, and takes approximately $7 \mathrm{~min}$, repeating every $10 \mathrm{~min}$. The beamwidth is approximately $1^{\circ}$ and the radar gate sizes are $500 \mathrm{~m}$ for all radars except Mumbai, which has a $300 \mathrm{~m}$ gate size. Geographical coordinates and further technical specifications of each radar are shown in Table 1. A rigorous calibration procedure is applied for each radar following the methods of Warren et al. (2018) and Louf et al. (2019), with the basic procedure as follows. Ground clutter (available from the total power data) is used to establish changes in calibration for each day over the season. Variability in the ground clutter distribution is corrected to an arbitrary reflectivity baseline, i.e., the relative calibration adjustment Louf et al. (2019). The corrected radar data is then compared to the GPM Satellite Ku-band radar product to assess the absolute calibration (Warren et al., 2018) over the season. The median difference between the radar and satellite reflectivity is averaged over several volume matches for each site. This offset is applied to the reflectivity data, which is iteratively corrected against GPM until the difference is calculated to be less than $1 \mathrm{~dB}$, at which point the radar is assumed to be calibrated to within that error. This two-step, iterative volume-matching technique for weather radar calibration is outlined in Figure 8 of 
Table 1

Relevant Specifications for the Seven Doppler Radars Used in This Study, Grouped by Region

\begin{tabular}{|c|c|c|c|c|c|c|}
\hline Site $^{\mathrm{a}}$ & Lat $\left({ }^{\circ} \mathrm{N}\right)$ & Lon $\left({ }^{\circ} \mathrm{E}\right)$ & Alt (m) & Gate size $(\mathrm{m})$ & Beamwidth $\left(^{\circ}\right)$ & Noise at $100 \mathrm{~km}(\mathrm{~dB})$ \\
\hline Chennai (VOMM) & 13.07 & 80.29 & 35 & 500 & 1.00 & 2 \\
\hline Machilipatnam (VOMP) & 16.18 & 81.15 & 35 & 500 & 1.00 & 2 \\
\hline Bhopal (VABP) & 23.24 & 77.42 & 570 & 500 & 0.93 & 0 \\
\hline Lucknow (VILK) & 26.77 & 80.88 & 143 & 500 & 0.97 & 3 \\
\hline Agartala (VEAT) & 23.89 & 91.25 & 35 & 500 & 0.93 & -1 \\
\hline Kolkata (VECC) & 22.57 & 88.35 & 35 & 500 & 1.00 & 2 \\
\hline Mumbai (VABB) & 18.90 & 72.81 & 100 & 300 & 1.00 & 2 \\
\hline
\end{tabular}

Note. The noise at $100 \mathrm{~km}$ is the minimum detectable signal calculated using a random day of clear-sky data for each radar. A clear-sky day is simply determined as any day with no measured rainfall that is also persistently clear in infra-red satellite imagery.

${ }^{a}$ The elevation angles for all radars are: $0.2^{\circ}, 1.0^{\circ}, 2.0^{\circ}, 3.0^{\circ}, 4.5^{\circ}, 6.0^{\circ}, 9.0^{\circ}, 12.0^{\circ}, 16.0^{\circ}$, and $21.0^{\circ}$.

Louf et al. (2019). The calibration correction applied to the seven radars varies between 0.0 and $6.5 \mathrm{~dB}$, with a mean of $3.4 \mathrm{~dB}$. Further quality control procedures are applied to the radar data automatically by the IMD. This includes the removal of ground clutter and anomalous propagation echoes in the reflectivity data by specialist software, and is described in more detail in Roy Bhowmik et al. (2011).

The primary method surrounds the construction of a vertical profile of radar data in Cartesian coordinates-also known as a Constant Altitude Plan Position Indicator (CAPPI) - transformed from its native polar coordinates. This grid is constructed using the Wradlib module for Python (Heistermann et al., 2013). The Cartesian grid consists of 28 vertical levels at $0.5 \mathrm{~km}$ resolution from a base of $2 \mathrm{~km}$, chosen to be above any clutter near the surface but below the freezing level so as to avoid brightband effects (usually at around $5 \mathrm{~km}$ over India during the Boreal summer; Harris et al., 2000). A range of 40-100 km is considered to avoid the "cone of silence" close to the radar up to the maximum height of the grid at $16.0 \mathrm{~km}$, and because of increasing noise level for the radars as range increases as well as beam broadening effects. Large cumulonimbus towers may exceed $16 \mathrm{~km}$ during the monsoon season. However, the largest elevation angle in the IMD radar scanning strategy is $21^{\circ}$. The center of this beam will intersect the $16 \mathrm{~km}$ level when it is a horizontal distance of approximately $40 \mathrm{~km}$ from the radar. Any further restrictions in the size of our horizontal domain in order to capture higher clouds would reduce the number of sampled cells and as we have only one season of data, we opted to prioritize the size of the horizontal domain. Cells with reflectivity at $16 \mathrm{~km}$ will be given a CTH of $16.5 \mathrm{~km}$. Although, its true CTH may be higher, this uncertainty does not affect our results once we group cells into categories by CTH.

The horizontal resolution of the grid is $1 \times 1 \mathrm{~km}$. At each elevation, for each Cartesian pixel, we find all grid points within $3 \mathrm{~km}$ and calculate the average reflectivity, weighted by the inverse square of its distance from the radar site. This distance was chosen as a trade-off between a smooth Cartesian grid of reflectivity and the retention of original features. Interpolation is carried out in $\mathrm{dBZ}$ following the recommended procedure for deriving ETH by Warren and Protat (2019). Whilst Wradlib was used to construct the Cartesian 3-D grid, its CAPPI algorithm introduced significant artificial annular ring features at regular intervals around the radar above and including the brightband region. These occur as a result of increasingly large spatial gaps between sweeps and the effects of melting precipitation. We therefore apply our own algorithm, whereby the vertical profile $(0.5 \mathrm{~km}$ grid) is calculated by linearly interpolating vertically across all elevation scans for each Cartesian pixel. This removes most of the annular ring artifacts, although some anomalies remain present after CAPPI construction, especially in the brightband $(5-7 \mathrm{~km})$ region and at higher altitudes. We do not expect these artifacts to greatly influence our results, given the subsequent processing of the data.

\subsection{Derivation of Echo-Top Height and Cell-Top Height}

To calculate radar-derived ETH, that is to say, the highest observed altitude of reflectivity for each pixel, a threshold for what constitutes a meteorological value must be applied. The choice of threshold must be greater than the noise level at $100 \mathrm{~km}$ (the outer-edge of our domain). This threshold is set to $5 \mathrm{dBZ}$, which 
is higher than the minimum detectable signal for all radars at $100 \mathrm{~km}$, as shown in Table 1 . Specifically then, searching upwards from $2 \mathrm{~km}$, the pixel nearest in value to $5 \mathrm{dBZ}$ in the vertical column is taken as the ETH, with the condition that there must be retrievals greater than $5 \mathrm{dBZ}$ at each $0.5 \mathrm{~km}$ level in the vertical column below the ETH. The spatial gaps between sweeps may lead to under- and overestimates of ETH, especially further from the radar where the separations become greater, and for higher elevation angles. However, these errors are reasonably predictable for a given scan strategy and vary with ETH and as a function of distance from the radar. In Appendix A, we carry out further analysis using data from a research radar, featuring high vertical resolution, on how the bias varies with range for the Indian radar scan strategy. We find that for ETH below $10 \mathrm{~km}$, the bias is typically less than $1 \mathrm{~km}$ and the mean bias is close to $0 \mathrm{~km}$.

This level of accuracy is sufficient for the purpose of our study, first, because we aggregate our ETH into single CTH values for each convective region (see below) and, second, because we are interested in the statistical variability of ETH averaged over a longer period of time. Such an approach has successfully been carried out in numerous studies for the Australian monsoon using the Darwin CPOL radar (Jackson et al., 2018; May \& Ballinger, 2007; V. V. Kumar et al., 2013), which has similar gaps between elevation angles compared to the IMD radars. For the CPOL ETH estimates, Jackson et al. (2018) reported a statistically significant correlation with satellite-retrieved cloud top heights, demonstrating the suitability of using radar-derived ETHs for analysis of convection over a monsoon season.

Next, we define CTH, which is the maximum ETH in a convective region. A convective region is any connected region of convective pixels, which is determined from the base CAPPI at $2 \mathrm{~km}$ following the method of Steiner et al. (1995):

1. Any pixel $\geq 40 \mathrm{dBZ}$ is automatically considered convective.

2. Any pixel greater than a background state by the reflectivity difference depicted in Figure 7 of Steiner et al. (1995) is convective.

3. Each convective pixel has a convective radius of a certain size as a function of intensity. A cell then is any connected set of convective pixels, and hence is termed a cell here, as a typical cumulonimbus cloud would have convective and stratiform segments.

The assumption is that if a pixel is convective at $2 \mathrm{~km}$, it is convective throughout its vertical extent. Due to small 2-12 km vertical shear at all sites during the monsoon season $\left(<10^{-3} \mathrm{~s}^{-1}\right)$, this is considered a fair assumption. Therefore, any inaccuracies stemming from tilting of the convective core due to vertical shear or cloud movement within the 7-min radar volume are further reduced by taking all connected pixels when calculating CTH. One limitation of applying the method of Steiner et al. (1995) in this manner is that elevated convection with no convective signal at $2 \mathrm{~km}$ will not appear in this study. However, due to very moist conditions in the lower troposphere during the monsoon, such occurrences are assumed to be small in number.

Attenuation is considered to be negligible for S-band radars, except for the most intense convective storms where hail is present (Testud et al., 2000). Such storms do occur during the ISM but are assumed to constitute a small proportion of our large, final sample. Therefore, attenuation correction is not performed. Only cells with a surface area (at $2 \mathrm{~km}$ height) of at least $4 \mathrm{~km}^{2}$ (4 pixels) are included in this analysis, as cells smaller than this dominate the statistics but do not represent true convection. Finally, any cell touching the inner or outer edges of the 40-100 km domain is not considered so that we always sample entire cells.

\subsection{Auxiliary Datasets and Method}

The convective cell statistics presented are considered in the context of the local and large-scale meteorological state during the 2016 monsoon season. The Integrated Multi-satellitE Retrievals for GPM product (hereafter referred to as IMERG), provides half-hourly robust precipitation estimates (Huffman et al., 2020), at $0.1^{\circ}$ horizontal resolution. This allows visualization of the large-scale precipitation field.

IMD gridded daily rainfall accumulations (Rajeevan et al., 2006), with $1^{\circ}$ spatial resolution, are used to designate active and break days in 2016 (and are also used in Figure 1b). We follow the method of Rajeevan et al. (2010) with a few adjustments: June-September 2016 IMD gridded daily rainfall is compared to the recent climatological (2008-2017) rainfall, averaged across a central India zone $\left(18-27^{\circ} \mathrm{N}\right.$ and $\left.73-82^{\circ} \mathrm{E}\right)$. A 
Table 2

2016 Indian Monsoon Season Active and Break Spells

\begin{tabular}{lc}
\hline Date & Active/break \\
\hline June 1-3 & Break \\
June $9-17$ & B \\
June $28-30$ & Active \\
July $2-7$ & A \\
July $9-13$ & A \\
July 20-26 & B \\
August 2-4 & A \\
August 12-14 & B \\
August 19-21 & A \\
September 3-12 & B \\
September 14-17 & A \\
September $21-28$ & A \\
\hline
\end{tabular}

Note. The method used to obtain these dates is described in the text. standardized rainfall anomaly is then calculated for each day, defined as the climatological average subtracted from the 2016 value, divided by the standard deviation of the climatological average. A difference between each day's standardized anomaly and the 2016 mean standardized anomaly that is greater than 0.7 defines an active day, and conversely a difference less than -0.7 defines a break day. Finally, an active/break day must be part of a set of 3 consecutive active/break days in order to be included in our statistics. The active and break days derived in this manner may not necessarily be part of true active and break periods, but instead more closely represent active and break spells with respect to the 2016 mean state, and their corresponding large-scale pattern changes. As a result, we identify a larger and more equal number of active and break days, lending itself to a more robust and fair comparison. The final active and break days used for this study are presented in Table 2 . Handily, there are 32 active and 32 break days across the season (26\% of the full sample in each case).

ERA5 (ECMWF Re-Analysis) estimates of several atmospheric variables at multiple levels are also used to complement this analysis over the 2016 season (Hersbach et al., 2020). Owing to the hourly resolution of ERA5, the diurnal cycle can be explicitly determined. Finally, twice daily (00 and 12 UTC) atmospheric soundings are available in the near vicinity $(<25 \mathrm{~km})$ of all sites analyzed here, and can be freely downloaded from the University of Wyoming Atmospheric Soundings web-page (http://weather.uwyo.edu/upperair/sounding.html). In the case of both IMERG and ERA5, when comparing fields at local radar sites, the average of all gridboxes with centroids in the $40-100 \mathrm{~km}$ radar domain is used.

\section{Individual Cell Statistics}

We start by examining the number of cells of different heights for each site, and relate these patterns to near-surface cell reflectivity. Table 3 shows the number of cells at each site and as an average per radar volume. Agartala has by far the largest number of cells, situated in the very convectively active north-eastern India region, with prevailing low-level winds originating from over the very moist Bay of Bengal (Figure 1b). Mumbai has noticeably fewer volumes over the season, owing to substantial periods of missing data during July and August in particular, and so should be analyzed with more caution. Considering the ratio of number of cells to number of radar volumes as a measure of convective activity (fourth column of Table 3), Agartala is by far the most convectively active, then all other sites average approximately three cells per radar volume over the entire season.

The probability of cell occurrence in each $0.5 \mathrm{~km} \mathrm{CTH} \mathrm{bin} \mathrm{is} \mathrm{shown}$ in Figure 2a. There is consistency between all 7 sites in the shape of this function, with a peak in $\mathrm{CTH}$ at approximately $6-8 \mathrm{~km}$, around or just a bit above the average freezing level during the monsoon (Harris et al., 2000). The two northern India sites-Bhopal and Lucknow-have the maximum $\mathrm{CTH}$ occurrence at a greater height, as well as the highest proportion of very deep ( $\mathrm{CTH} \geq 12 \mathrm{~km}$ ) cells. Several sites (Chennai, Machilipatnam, Bhopal, and Lucknow) display the hint of a secondary peak in CTH at $12-13 \mathrm{~km}$, associated with deep convection. However, this peak is not obvious, as Figure 2 is an average over the entire season, throughout which different cloud regimes, some dominated by shallower convection, will occur. Indeed, taking especially convectively active weeks displays the secondary peak much more clearly (not shown). 

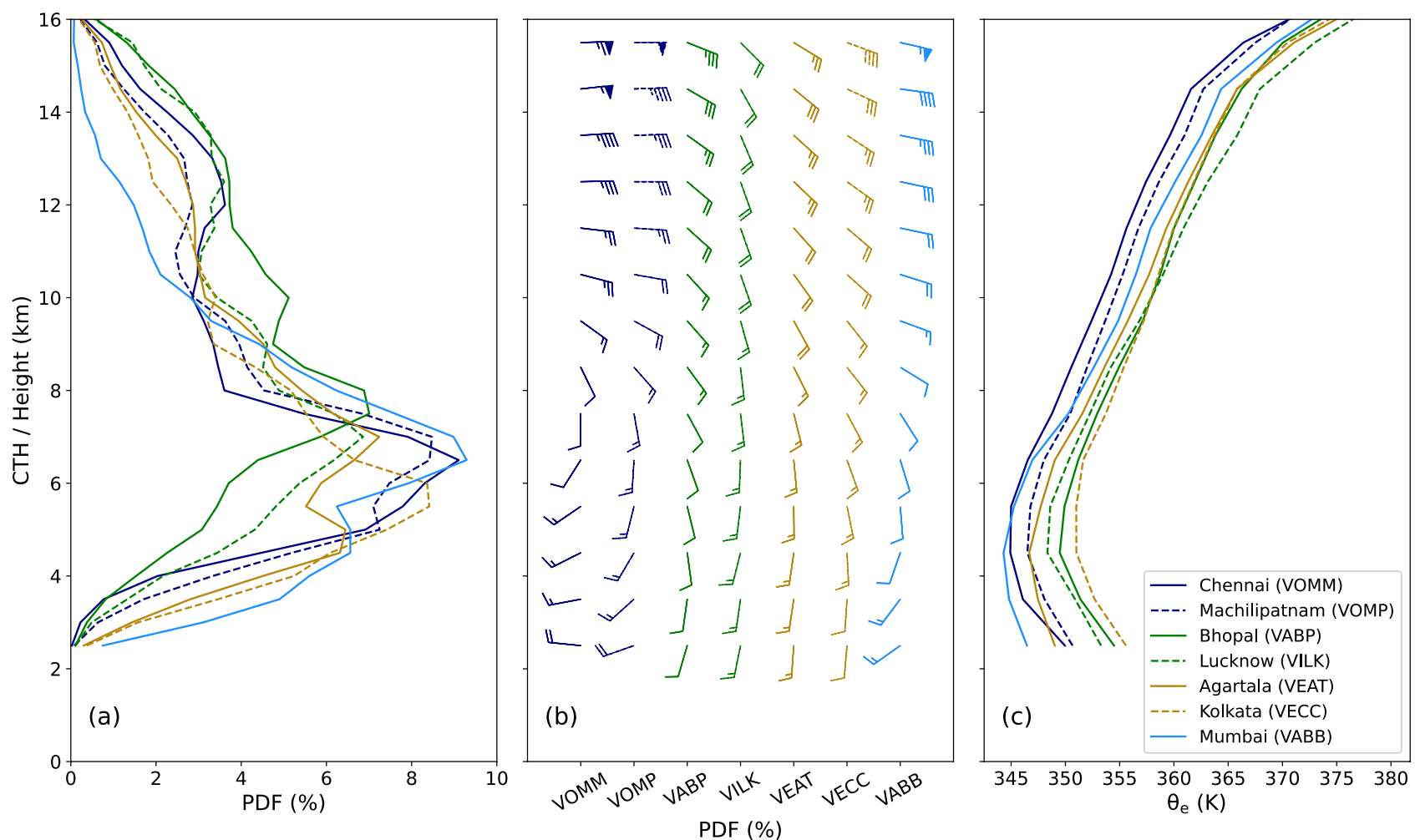

Figure 2. (a) Percentage of different cell-top heights (CTHs) for the seven radars used in this study as shown in Figure 1 , from $2.5 \mathrm{~km}$ above the surface, every $0.5 \mathrm{~km}$ in height, (b) wind barbs from local soundings every $1 \mathrm{~km}$ in height with barb increments denoting 5,10 , and $50 \mathrm{knots}$, respectively, and (c) equivalent potential temperature $\left(\theta_{\mathrm{e}}\right)$ every $1 \mathrm{~km}$ in height also from local soundings. Radars in different regions are grouped by color. The PDF does not include CTH $>$ $16 \mathrm{~km}$ (see Table 3).

Evidence of such bimodality was also found during the Austral monsoon season at Darwin by Jackson et al. (2018), especially during the more active phases of the Madden-Julian Oscillation when mid-level moisture was found to be higher. Therefore, Figure 2a suggests the presence of at least 2 cumulus modes, one around the freezing level, and one in the upper troposphere. This will be explored in more detail later in this section.

Mumbai exhibits a larger proportion of shallow convection $(\mathrm{CTH}<5 \mathrm{~km})$, and a smaller proportion of deep convection relative to other sites. While the Mumbai data are predominantly unavailable from July, this is consistent with previous observational analysis for the region (e.g., Utsav et al., 2017). Das et al. (2017) found rain in the Western Ghats region to be dominated by shallow-convective systems (echo tops below the melting layer). Mid-tropospheric air from Mumbai radiosonde soundings in 2016 is found to be drier on average compared to the other regions (not shown), consistent with the findings of S. Kumar (2017). Das et al. (2017) also commented on the role of orography, showing that convective clouds over the Western Ghats precipitate out quickly owing to rapid collision-coalescence of cloud droplets due to orographic uplift.

The vertical wind profiles in Figure $2 \mathrm{~b}$ show the presence of the tropical easterly jet (TEJ) upwards of $8 \mathrm{~km}$, a major component of the large-scale monsoon circulation in Boreal summer (Krishnamurti \& Bhalme, 1976). It forms as a result of the meridional temperature gradient between the subtropics and equatorial Indian Ocean in the upper troposphere. Mumbai and south-eastern India exhibit westerly or south-westerly winds in the low and mid-troposphere, with strong easterly winds associated with the TEJ in the upper troposphere. Interestingly, the transition to easterly at around 6-8 $\mathrm{km}$ above the surface is where the winds are weakest, and this is approximately the height of the modal CTH for these sites. The presence of stronger winds aloft associated with the TEJ may be an inhibiting factor for vertical cell growth, as the strong wind shear can spread cloud tops above $8 \mathrm{~km}$ (Sathiyamoorthy et al., 2004). This can act as one constraint on CTH, especially during peak monsoon months when the TEJ is strongest. For northern and north-eastern India, there is a deep layer of southerly winds in the lower and middle-troposphere, with 
(a) Chennai (VOMM)

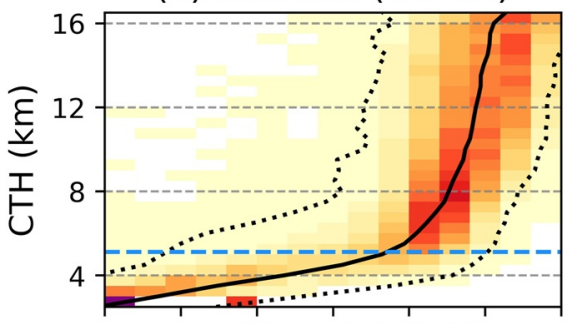

(c) Bhopal (VABP)

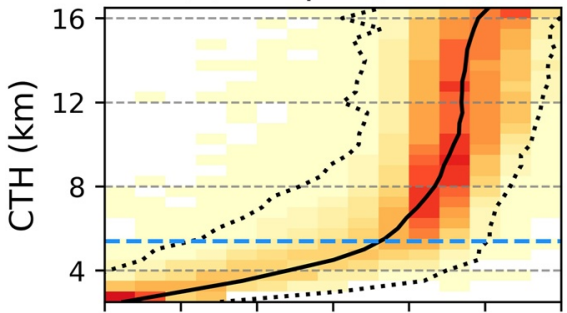

(e) Agartala (VEAT)

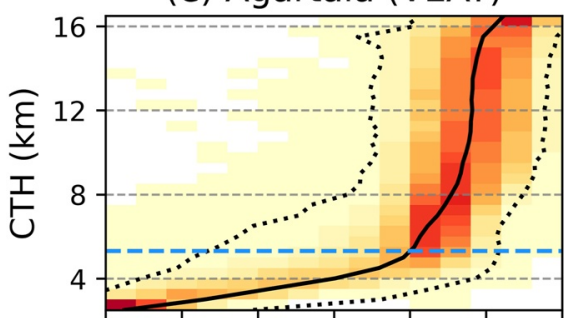

(g) Mumbai (VABB)

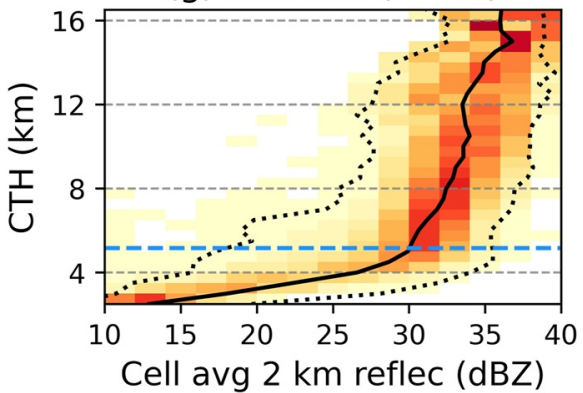

(b) Machilipatnam (VOMP)

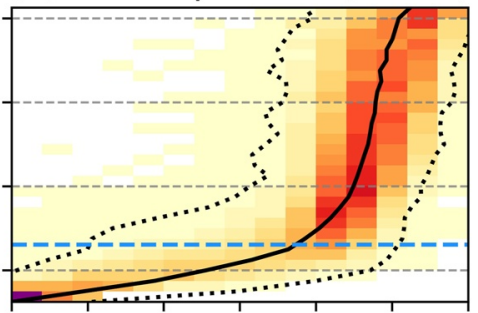

(d) Lucknow (VILK)

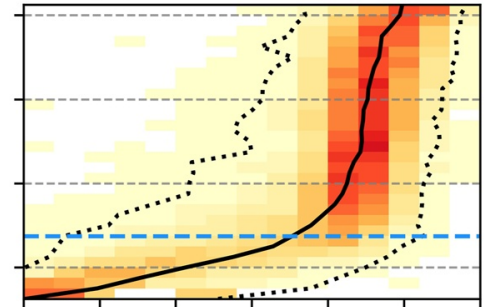

(f) Kolkata (VECC)

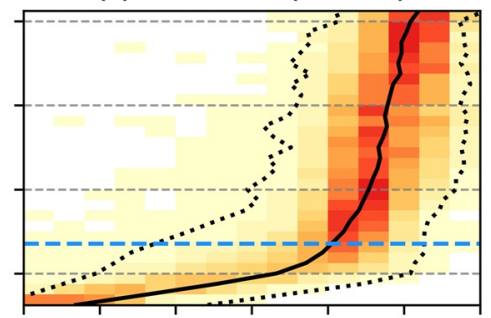

(h) Composite

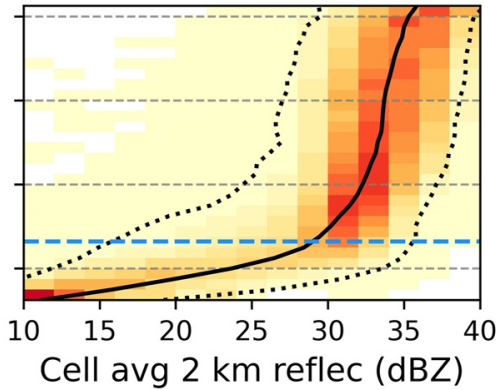

Figure 3. PDF of $2 \mathrm{~km}$ cell average reflectivity using a bin size of $2 \mathrm{~dB}$ and as a function of cell-top height (CTH) (not including CTH > 16 km). (a) Chennai, (b) Machilipatnam, (c) Bhopal, (d) Lucknow, (e) Agartala, (f) Kolkata, (g) Mumbai, and (h) a composite of all sites. The black solid line is the mean reflectivity at each CTH, with dotted lines denoting the 5th and 95th percentiles. The dashed horizontal blue line is the height of the average freezing level from local radiosonde profiles.

a small amount of gradual backing of these winds with height. Wind speeds only begin to increase above $8 \mathrm{~km}$, again above the modal peak in CTH for these sites. The increase in wind speed is more subtle for Lucknow (VILK), where weaker upper-level wind shear may contribute to the marginally higher proportion of very deep cells here $(\geq 12 \mathrm{~km})$, due to less spreading of cloud tops.

As aforementioned, Figure 2a suggests the presence of multiple cumulus modes (preferential detrainment of cloud tops at certain levels), and we investigate this and its associated mechanisms in more detail here, by analyzing the relationship between $\mathrm{CTH}$, equivalent potential temperature $\left(\theta_{\mathrm{e}}\right.$; Figure $\left.2 \mathrm{c}\right)$ and near-surface reflectivity (Figure 3). This analysis is important because the different cumulus modes in Figure $2 \mathrm{a}$ are likely to have different characteristics and may interact with the large-scale environment in different ways. First, Figure 3 shows that $2 \mathrm{~km}$ cell reflectivity is clearly a definitive indicator of CTH for all sites. More intense cells (higher $2 \mathrm{~km}$ reflectivities) typically have higher cell tops (and are greater in horizontal extent, 
not shown here). Reflectivity values of $20 \mathrm{dBZ}$ indicate light rain $\left(<1 \mathrm{~mm} \mathrm{hr}^{-1}\right), 30 \mathrm{dBZ}$ moderate rain $\left(>1 \mathrm{~mm} \mathrm{hr}^{-1}\right)$, and $40 \mathrm{dBZ}$ heavy rain $\left(>10 \mathrm{~mm} \mathrm{hr}^{-1}\right)$ and so higher cells are also associated with heavier precipitation. Mumbai exhibits a higher average $2 \mathrm{~km}$ reflectivity for shallow CTH (27 dBZ at $4 \mathrm{~km}$ compared to $24 \mathrm{dBZ}$ at $4 \mathrm{~km}$ for the composite of all sites), suggesting low cell tops are associated with heavier rainfall here. As discussed previously, this is a direct impact of the surrounding orography, which causes rapid collision-coalescence of raindrops in shallow convection. Although our Mumbai analysis is weighted toward May and June, these results are consistent with recent findings using both TRMM (Shige \& Kummerow, 2016; S. Kumar \& Bhat, 2017), and ground-based weather radars (Utsav et al., 2019). The ability for shallow convection (with warmer cloud tops) to produce high rainfall rates in this region has implications for conventional satellite rainfall algorithms which relate precipitation to cloud top brightness temperature (Shige \& Kummerow, 2016). Studying Figure 3h, the shallowest cells are associated with very low reflectivity and have a broad reflectivity distribution, with large variance in the intensity of these shallow cells, as indicated by the 5-95 percentile range. For shallow cells, the variance of the composite (Figure $3 \mathrm{~h}$ ) is $35 \mathrm{dBZ}$ as opposed to $7 \mathrm{dBZ}$ for deep cells. As CTH increases there is initially a rapid rise in reflectivity until approximately $30 \mathrm{dBZ}$. At this point, $\mathrm{CTH}$ is on average $5-7 \mathrm{~km}$, in the region of the freezing level (dashed blue line) and the modal CTH over the season. This is also the approximate region of maximum atmospheric stability (as shown by the minima in the vertical profiles of $\theta_{\mathrm{e}}$ in Figure 2c), and is associated with a narrowing of the reflectivity distribution (scanning horizontally between the black dotted lines in Figure 3). The stable layer near the freezing level forms physically as a result of latent heat release due to precipitation freezing and melting processes (Posselt et al., 2008). Above this level, there is a smaller increase in reflectivity with CTH. Furthermore, around $12 \mathrm{~km}$ the temperature lapse rates (not shown) increase to quasi-dry adiabatic with remarkable consistency between all sites hinting at the regulatory and homogeneous influence of the largescale monsoon pattern upon different regions in India. Around $10 \mathrm{~km}$ there is a small atmospheric layer of constant reflectivity with increased CTH for some of the sites (e.g., Bhopal, Lucknow, Mumbai). This is likely because clouds that penetrate to this level encounter considerable atmospheric instability associated with steep temperature lapse rates and shear-driven instability from the TEJ. Therefore, these cells can grow deeper without any significant increase in intensity.

Therefore, the convective modes identified from Figure 2a show distinct characteristics in terms of intensity and can be related to atmospheric stability. The first mode is shallow convection ( $\mathrm{CTH}<5 \mathrm{~km})$, associated with highly variable, but on average low $2 \mathrm{~km}$ reflectivity (rapidly increasing with each $0.5 \mathrm{~km} \mathrm{CTH} \mathrm{bin).}$ The second mode represents cumulus congestus clouds $(5-8 \mathrm{~km})$. These cells are bounded by the maximum in atmospheric stability above the freezing level and so the $2 \mathrm{~km}$ average reflectivity values remain less than $35 \mathrm{dBZ}$. This is also visible as the modal peak in cells around this region for all sites (Figure 2a). The third mode (deep convection) penetrates above the region of stability associated with the freezing level $(\geq 8 \mathrm{~km})$, and exhibits the most vigorous convection with average $2 \mathrm{~km}$ reflectivity values of approximately $35 \mathrm{dBZ}$. When referring to shallow, congestus, and deep convection throughout this study, we refer to these CTHs. These modes were also found by V. V. Kumar et al. (2013) for Darwin in Austral summer (in addition to an overshooting top mode which we are unable to investigate here due to 3-D grid restrictions). However, our results in contrast show more of a continuous increase in mean $2 \mathrm{~km}$ reflectivity as CTH increases above the freezing level. This may stem from the spreading of cloud tops by the TEJ above $8 \mathrm{~km}$, except for the largest and most intense cells. To summarize, for all sites, the statically stable layer around the freezing level (Figure 2c) acts as a constraining factor upon $\mathrm{CTH}$, and this manifests itself as a reduction in the gradient of $2 \mathrm{~km}$ reflectivity around this level (Figure $3 \mathrm{~h}$ ). When discussing the cell patterns over the diurnal cycle in Section 5, we will consider the mean diurnal cycle of these separate convective modes as well. Similar analysis sub-sampled by intraseasonal variation is provided as Supporting Information S1.

\section{Cell Patterns Over Active and Break Periods}

Active and break spells are the foremost manifestation of systematic intraseasonal variability during the ISM. These oscillations occur in most of the elements of the monsoon system, and are highly pronounced in monsoon cloudiness (Krishnamurti \& Bhalme, 1976). Here, we analyze how the active and break spells in 2016 (Table 2) affect the height of convective cells in each region. Figure 4 displays the distributions of $\mathrm{CTH}$ for active and break periods at each site, alongside vertical profiles of horizontal wind and $\theta_{\mathrm{e}}$ from 
(a) Chennai (VOMM)

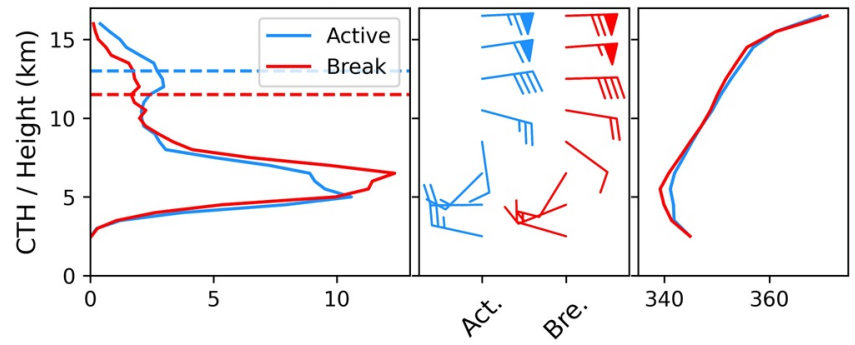

(c) Bhopal (VABP)

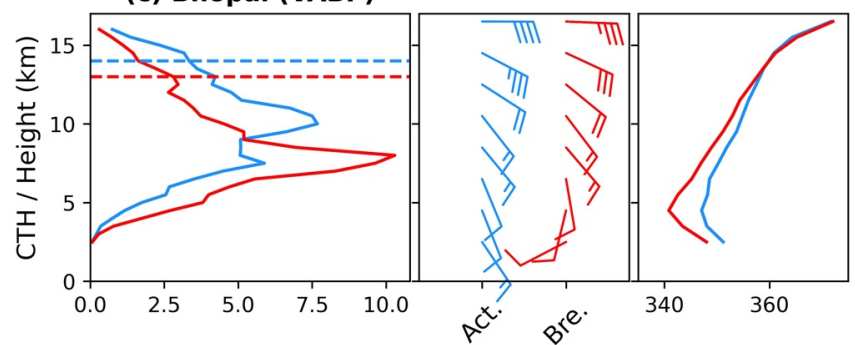

(e) Agartala (VEAT)

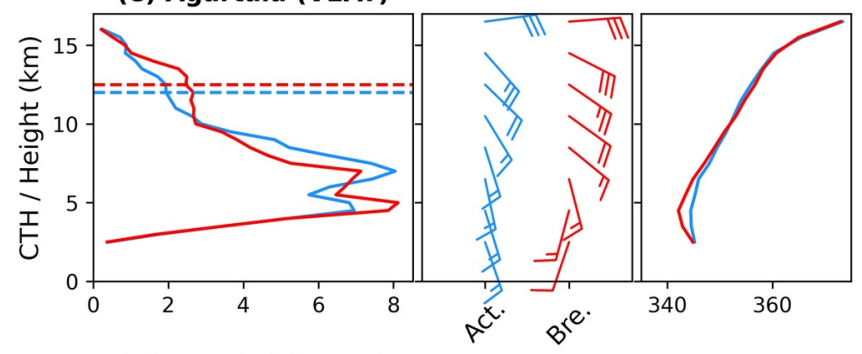

(g) Mumbai (VABB)

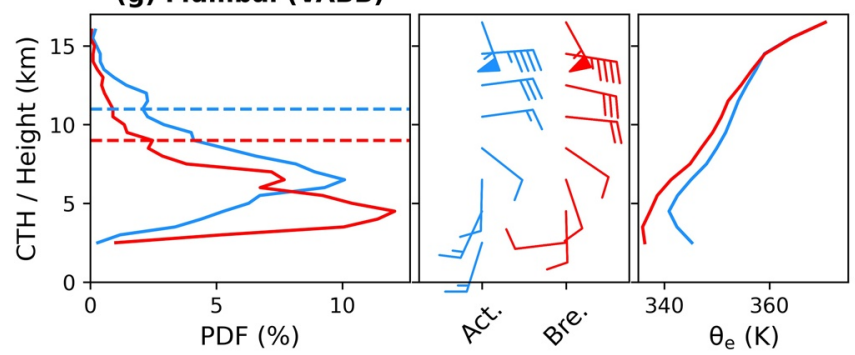

(b) Machilipatnam (VOMP)

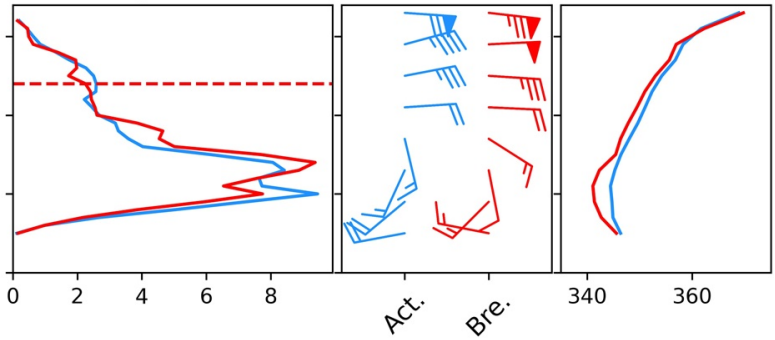

(d) Lucknow (VILK)

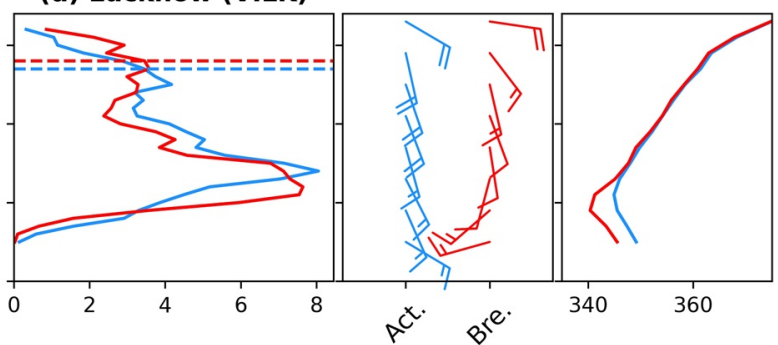

(f) Kolkata (VECC)

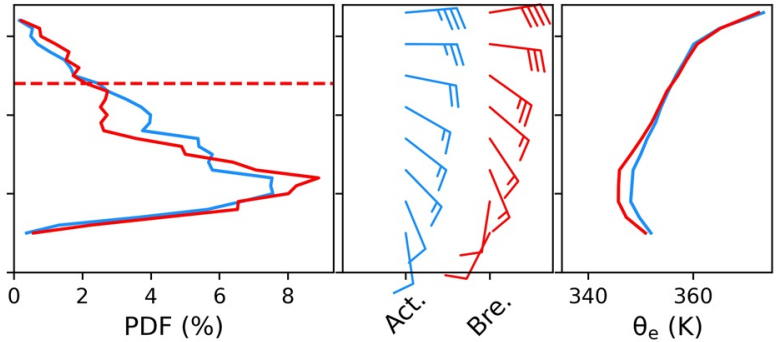

Figure 4. Same as Figure 2, but the cell-top height (CTH) distributions, wind barbs, and $\theta_{\mathrm{e}}$ profiles are shown separately for each site (a-g) as in Figure 3, where the blue lines/barbs are for all active days and red for all break days, as given in Table 2 . The horizontal dashed blue and red lines show the 90 th percentile in the distribution of $\mathrm{CTH}$ for active and break periods respectively.

soundings. Bhopal, Lucknow and Mumbai form part of the central India gridbox that is used here to monitor anomalous rainfall and active and break spells. As a result, we expect to see more frequent deep convection in active periods at these sites. Mumbai and Bhopal exhibit this most discernibly in both the mode and 90th percentile of the CTH distributions. This pattern of deeper convection is associated with a clear increase in $\theta_{\mathrm{e}}$ for Mumbai and Bhopal, most starkly in the region of the freezing level, but indeed through a large part of the troposphere. Interestingly, Lucknow shows little difference between active and break CTH distributions, despite also displaying a clear increase in instability below $6 \mathrm{~km}$. Potential causes for the similar distributions will be explored later in this section. The changes in the wind profiles for these locations between active and break periods are subtle at higher altitudes where the TEJ dominates. However, the winds nearer the surface are slightly stronger in magnitude for Bhopal and Mumbai, with different directional components suggesting the importance of lower tropospheric moisture advection for cumulus growth.

There is also little change between the CTH distributions of Agartala and Kolkata in north-eastern India (Figures 4e and 4f). Chennai and Machilipatnam also show no substantial change between active and break 
Table 4

For Each Site, the Number of Cells in Each Cumulus Mode Category for 2016 Active and Break Periods and the Average Number of Cells per Radar Volume

\begin{tabular}{lccccc}
\hline Site & Active/break & Shallow & Congestus & Deep & Cells per volume \\
\hline Chennai (VOMM) & Break & $806(9)$ & $5,268(61)$ & $2,615(30)$ & 2.1 \\
Machilipatnam (VOMP) & Active & $1,238(13)$ & $4,754(50)$ & $3,604(38)$ & 2.3 \\
Bhopal (VABP) & B & $836(13)$ & $3,045(47)$ & $2,533(39)$ & 1.5 \\
& A & $2,521(16)$ & $7,451(47)$ & $5,949(37)$ & 3.6 \\
Lucknow (VILK) & B & $477(5)$ & $3,068(35)$ & $5,151(59)$ & 2.2 \\
& A & $288(2)$ & $2,374(20)$ & $9,320(78)$ & 5.6 \\
Agartala (VEAT) & B & $241(5)$ & $1,729(39)$ & $2,433(55)$ & 2.4 \\
Kolkata (VECC) & A & $421(8)$ & $1,768(35)$ & $2,920(57)$ & 2.4 \\
Mumbai (VABB) & B & $4,119(18)$ & $9,005(40)$ & $9,302(41)$ & 6.4 \\
& A & $3,520(18)$ & $8,260(41)$ & $8,234(41)$ & 7.0 \\
& B & $1,675(20)$ & $3,609(43)$ & $3,119(37)$ & 3.0 \\
\hline
\end{tabular}

Note. The numbers in parentheses show the percentage of cells in that cumulus mode. Shallow mode $(\mathrm{CTH}<5 \mathrm{~km})$; congestus mode $(5 \leq \mathrm{CTH}<8 \mathrm{~km})$; and deep mode $(\mathrm{CTH} \geq 8 \mathrm{~km})$.

spells in the modal CTH. These four locations exhibit slight increases in instability in the freezing level region, but with small differences elsewhere, which suggests the importance of instability at upper levels as well as the freezing level for deep convective development. However, Chennai does exhibit a signal in active spells having more frequent deep convection, shown by the disparity in the 90th percentiles. For CTH < $8 \mathrm{~km}$, the distributions are very similar however. The split in the distributions above this level appears to be caused by an increase in the fraction of very deep cells $(\mathrm{CTH} \geq 12 \mathrm{~km})$ during active periods. It is important to recall that only convective cells are considered here. For example, T. N. Rao et al. (2016) found a higher occurrence and fraction of stratiform rain in active spells, due to the prevalence of large, organized storms such as mesoscale convective systems. This suggests that rainfall will not only be more intense but more long-lived, consistent with the typical longer lifetimes of stratiform rains (Steiner et al., 1995).

Table 4 shows the numbers and proportions of cells in the different cumulus mode categories as defined in Section 3 for active and break periods in 2016: shallow convection, cumulus congestus, and deep convection. Between active and break periods, similar proportions of cells in different modes are seen in Machilipatnam, Lucknow, Agartala, and Kolkata (consistent with Figure 4). An increase in the number of cells per radar volume from break to active periods occurs for all sites but Lucknow and Kolkata, where there is no or minimal change in this statistic. The increase in convection during active periods is most noticeable in Mumbai. Due to periods of unavailability in the data, Mumbai has 135 radar volumes during active periods mostly during June 28-30 , and partly August 2-4 and the September active spell dates. During break periods, there are 715 radar volumes mostly during the June break spell dates and partly September 3-12. For break spells represented by the Mumbai radar, there is a large reduction in the proportion of shallow convection, and a $21 \%$ increase in the proportion of deep convection. In Bhopal, deeper convection is also more likely in active spells, with a reduction in the proportion of the congestus mode. Chennai sees a reduction in the likelihood of the cumulus congestus mode during active periods, and a higher likelihood of shallow and deep cells, though the total amount of convection per radar volume is only marginally higher.

We further analyze these statistical patterns in the context of the large-scale circulation so as to understand what dynamic component of active and break spells drives convective variability in different locations. Anomalies in IMERG rainfall, ERA5 winds, and relative humidity between 2016 active and break periods are shown in Figure 5, along with contours of average mean sea-level pressure (MSLP). The rainfall anomalies (Figures $5 \mathrm{a}$ and $5 \mathrm{~b}$ ) provide the closest relationship to $\mathrm{CTH}$, with a narrow band of increased rainfall 
(a) Active

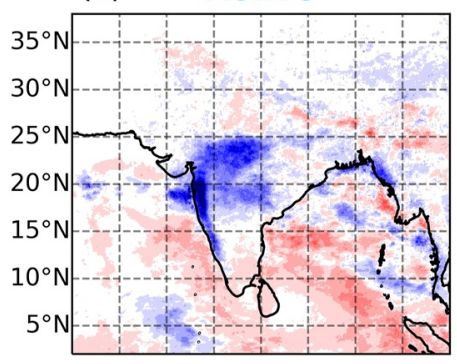

(c) $\rightarrow 3 \mathrm{~m} \mathrm{~s}^{-1}$

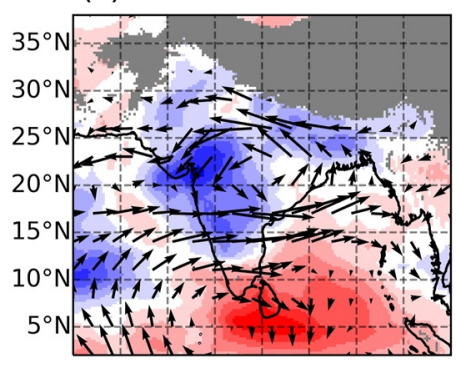

(e)

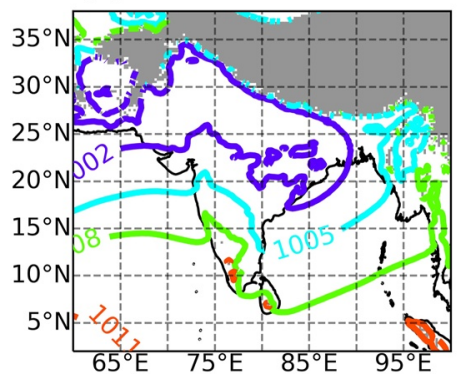

(b)

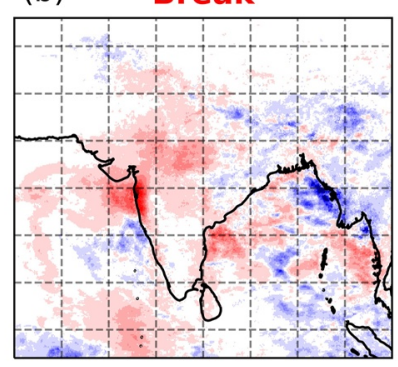

(d)

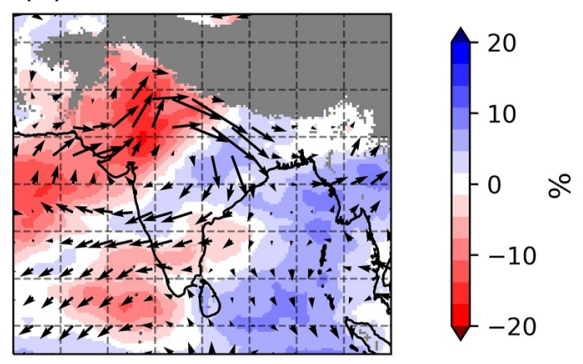

(f)

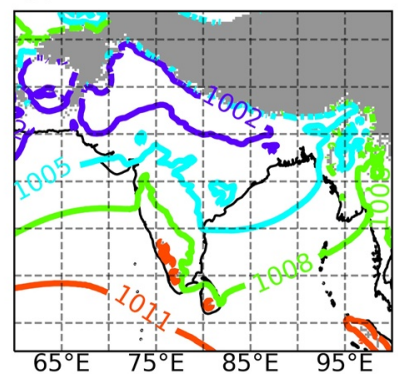

Figure 5. Large-scale patterns for the 32 active and 32 break days in 2016. (a-b) IMERG rainfall anomalies, relative to the entire season (c-d) $850 \mathrm{hPa}$ relative humidity (colors) and wind vector anomalies, (e-f) contours of average mean sea-level pressure in units of hPa. Gray shaded regions in the center and right columns are areas of topography over $1.5 \mathrm{~km}$.

down the Western Ghats region and a larger swathe over central and northern India during the active spells. The effect of convective enhancement over the Western Ghats means this positive rainfall anomaly remains confined to the coastal region south of $18^{\circ} \mathrm{N}$, despite anomalously strong westerly winds and high relative humidity extending further east (Figures $5 \mathrm{c}$ and $5 \mathrm{~d}$ ). This explains the lack of a definitive change in the distribution of CTH between active and break periods over south-eastern India (Figure 4). It is difficult to explain what may be causing the increase in deep convection in Chennai during active periods in 2016, and indeed how robust this feature is. At $26.8^{\circ} \mathrm{N}$, Lucknow falls just north of the region of increased rainfall during active spells. Over central India there are relatively much stronger westerlies during active periods. These winds then start to curve back toward the north-west over the Bay of Bengal, and so Lucknow experiences south-easterly winds in the lower troposphere, as it is positioned north of the monsoon trough. This results in less rainfall than the region of potent westerlies further south. In the transition to break periods the monsoon trough moves northwards to the foot of the Himalayas (shown by the northward push in the MSLP pattern from Figures 5e to 5f), bringing lower tropospheric westerlies further north to Lucknow. However, the background state is drier overall (Figure 5d), thus Lucknow exhibits no significant change in rainfall and the distribution of CTH. In north-eastern India, it is an even more complex picture, with small pockets of positive and negative rainfall anomalies in the region during 2016. To the east of Agartala $\left(91.25^{\circ} \mathrm{E}\right)$ along the Bay of Bengal coast, there is a more definitive area of increased rainfall and higher 
relative humidity during break periods, associated with enhanced southerly winds from the Bay of Bengal. The lack of a clear active-break driven signal over north-eastern India is likely responsible for the similar percentages of different cumulus modes in this region between active and break periods (Table 4).

\section{Cell Patterns Over the Diurnal Cycle}

The diurnal cycle is intrinsic to convection, as well as the local meteorology and land surface features of the region, and so its monsoonal behavior is important to understand. With time continuous radar observations of 10-min resolution, the diurnal cycle of convection is fully captured by the radar observations. Furthermore, Chennai, Machilipatnam, and Mumbai radar domains include both coastal land and ocean areas (Figure 1), allowing an analysis of the diurnal cycle over these different surface types. Finally, we will then investigate how the diurnal cycle is modulated by the progression of the monsoon through the season, and the active and break periods discussed in Section 4.

\subsection{Diurnal Cycle Cell Statistics}

The diurnal cycle of convective cells at every CTH bin is shown in Figure 6 with individual convective modes shown in Figure 7. Broadly speaking, observing the number of cells (at all CTH) through the day, we see distinct differences between the four different regions (and similarities within regions). Chennai and Machilipatnam display an overall night-time peak in the number of cells. Machilipatnam appears to show two peaks, one in the afternoon and a more prolonged peak overnight. We will see later how respective land and ocean convection contributes to this. IMERG rainfall (shown by the blue line in Figure 6 as a fraction of the daily total) exhibits a clear relationship with diurnal convective fraction, but most strongly with the more heavily precipitating deep convection. Assuming that convection dominates rainfall, we expect rainfall to be correlated with convective area (which is in itself correlated with the number of cells). More precisely, the rainfall appears to peak alongside the maximum in the number of deep cells $(\mathrm{CTH} \geq 8 \mathrm{~km}$, see Figure 7). As discussed in Section 3, deep convective cells are associated with higher $2 \mathrm{~km}$ reflectivity (and thus higher precipitation rates).

The effect of solar heating is clearly a larger source of influence for the inland sites Bhopal and Lucknow, with a convective peak in the afternoon and evening associated with maximum surface heating. Noticeably, IMERG rainfall is more constant through the day in comparison, although both sites exhibit an increase in rainfall into the evening a few hours after the peak in the number of cells, but well correlated with the peak in the fraction of deep convection (Figure 7c). Initially, there are a greater number of shallow and congestus cells associated with the afternoon peak in cell fraction. Some of these cells dissipate, and others grow and merge, meaning that as the number of cells decreases in the evening, the number of deep cells and the total area covered by convection nonetheless continues to increase for a few hours.

North-eastern India sees its peak in total cell number around noon and early afternoon, however, Agartala especially is prone to convection at all times of day. This explains the much larger number of cells per radar volume shown in Table 1, with no real convectively inactive time of day. Consistently high low-level moisture from the Bay of Bengal likely contributes to this. Interestingly, the peak in Agartala rainfall actually occurs at night, the opposite time of day to the peak in cell number. Figures 6e, 7e show a higher likelihood of deeper cells at night, whereas the daytime cells, whilst higher in number, are typically shallower. This appears to be a fairly localized effect however, as it is not seen further south and west in Kolkata, which instead shows one clear peak centered at 2 p.m. along with the peak in rainfall. Figure 7 shows that the cells in north-eastern India (and also Chennai) appear to deepen more quickly than those over northern India and Machilipatnam, meaning rainfall peaks more closely alongside the peak in the number of cells. Mumbai shows no diurnal cycle in cell number or rainfall, bar the slight suggestion of a night-time and an afternoon peak. Although the Mumbai analysis is dominated by May and June, the study of Romatschke and Houze (2011) supports this result. They noted using TRMM data that over the western Indian coast, small and medium sized systems are present throughout the day, as the prevailing south-westerly moisture laden flow is lifted over orography. The prevalence of shallow convection here also moderates the daytime temperatures relative to northern India, meaning there is less of a surface heating contribution upon convective initiation. 
(a) Chennai (VOMM)
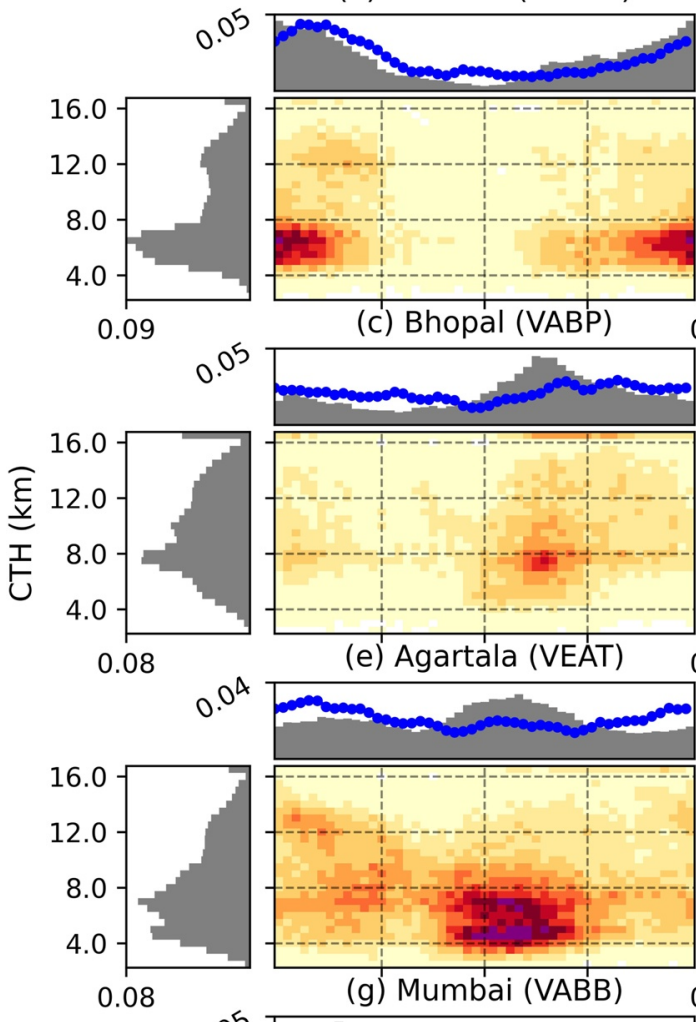

(c) Bhopal (VABP)

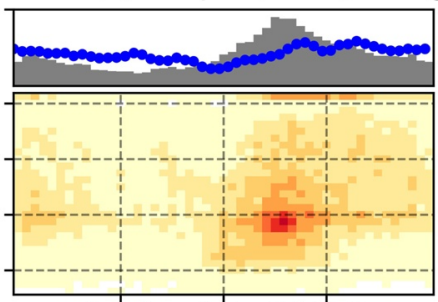

(e) Agartala (VEAT)

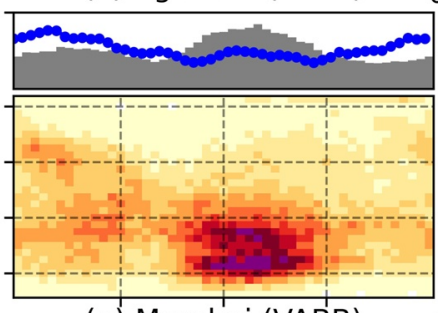

(g) Mumbai (VABB)

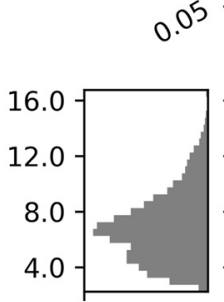

0.1

Fraction
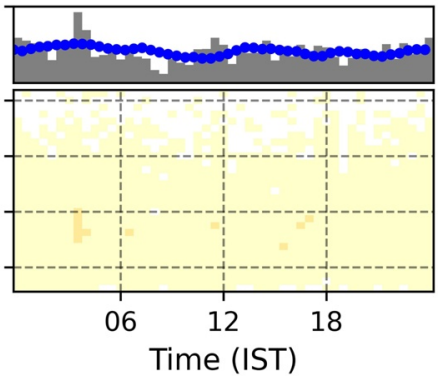

0.09

Fraction (b) Machilipatnam (VOMP)

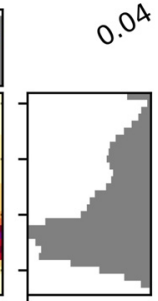

0.08
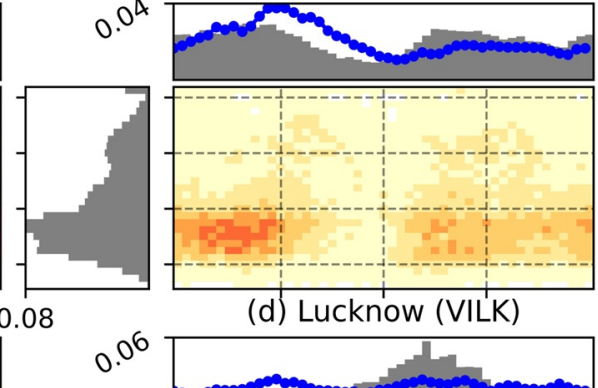

(d) Lucknow (VILK)

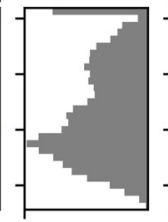

0.07

0.05

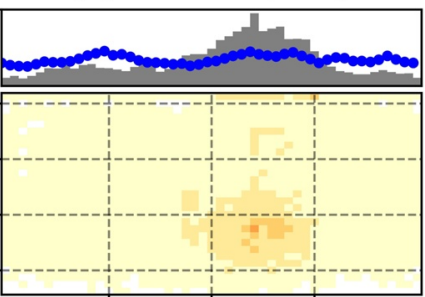

(f) Kolkata (VECC)
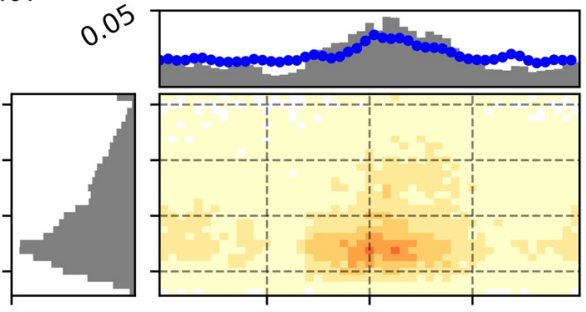

06

Time (IST)

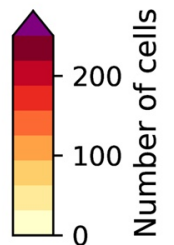

Figure 6. Number of cells as a function of the diurnal cycle (30-min bins) and cell-top height (CTH), with histograms representing the probability density of cell occurrence across each axis for (a) Chennai (VOMM), (b) Machilipatnam (VOMP), (c) Bhopal (VABP), (d) Lucknow (VILK), (e) Agartala (VEAT), (f) Kolkata (VECC), and (g) Mumbai (VABB). Includes $\mathrm{CTH}>16 \mathrm{~km}$. IST = Indian Standard Time $(\mathrm{UTC}+5.30)$. Pixels with 0 cells are masked white. The blue dotted line is the normalized diurnal cycle in IMERG precipitation as a mean over each IMERG gridbox whose centroid lies in the $40-100 \mathrm{~km}$ radar domain.

\subsection{Diurnal Cycle Over Land and Ocean}

We look in more detail at Chennai, Machilipatnam, and Mumbai by considering cells over land and ocean separately. These sites have the advantage of having nearly $50 \%$ of their domains over ocean, and $50 \%$ over land. For simplicity here, cells are judged to be land or ocean cells based off their centroids; $2 \%-4 \%$ of (generally larger) storms straddle the coast. First considering Chennai and Machilipatnam, Figures 8a and 8b shows clearly that there is higher rainfall and a greater cell number at night and in the early morning over the ocean compared to land. This is also a consistent pattern for all three cumulus modes (Figure S1). Either cells are simply forming later into the night on average offshore, or there is advection of cells from onshore to offshore as the evening progresses. If we consider that the 1-6 km vertical wind shear in south-eastern India is typically quasi-westerly through the day, it largely supports the advection hypothesis. That is to say, cells that form over land in the evening move with the quasi-westerly offshore wind shear. This theory is further supported by the similar shapes and amplitudes of the cycles between land and ocean. This suggests 
(a) Chennai (VOMM)

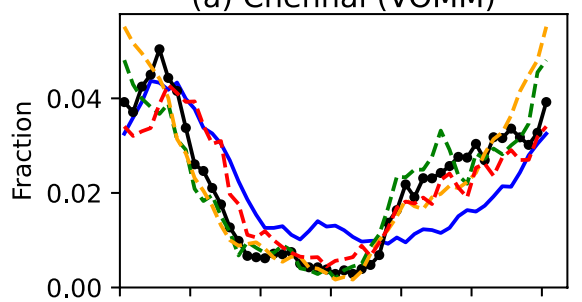

(c) Bhopal (VABP)

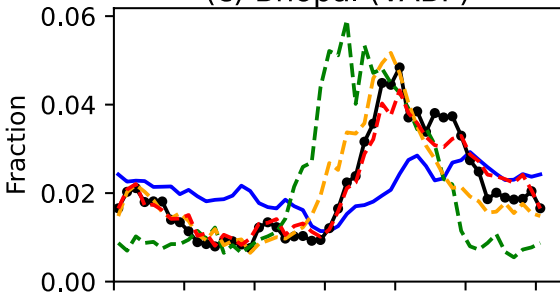

(e) Agartala (VEAT)

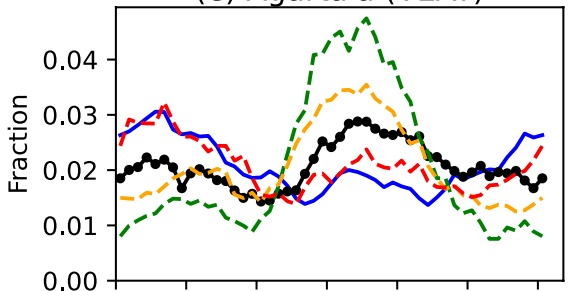

(g) Mumbai (VABB)

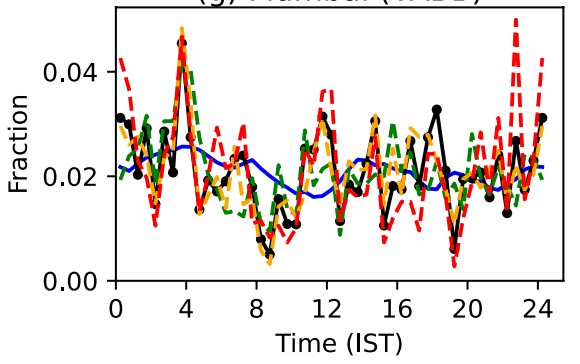

(b) Machilipatnam (VOMP)

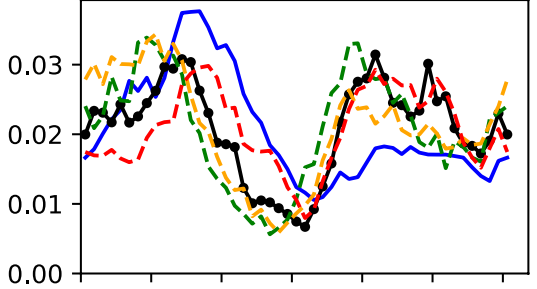

(d) Lucknow (VILK)

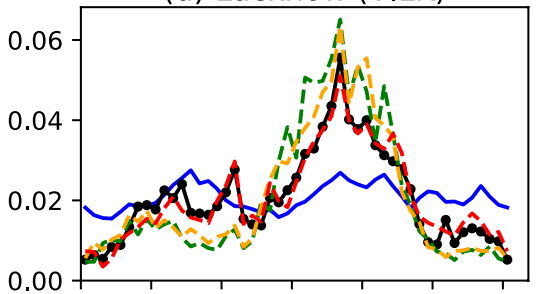

(f) Kolkata (VECC)

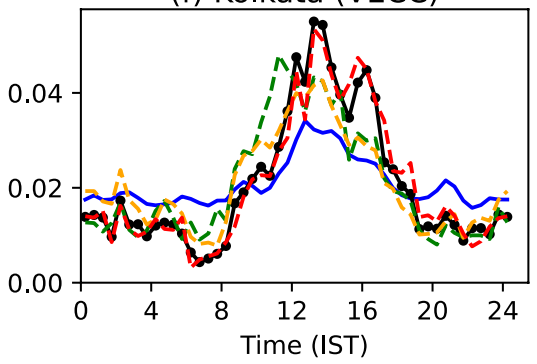

- IMERG

$\rightarrow$ Total conv. area

-- - Shallow

--- Congestus

-- - Deep

Figure 7. Same as Figure 6, but showing the normalized fraction of cells in different cumulus mode categories: shallow (cell-top height, $\mathrm{CTH}<5 \mathrm{~km})$; congestus ( $\leq \mathrm{CTH}<8 \mathrm{~km})$; and deep $(\mathrm{CTH} \geq 8 \mathrm{~km})$. The black line is the total convective area normalized over the diurnal cycle, and IMERG rainfall is as in Figure 6.

the spreading of the cloud tops over the ocean from coastal regions in the evening. This was also found for the Bay of Bengal by Yang and Slingo (2001). They suggested gravity waves and complex land-sea breeze effects as drivers of this process. On further study of Figure 8, there is a clear second peak in the height of cells (at about $13 \mathrm{~km}$ ) over ocean, but not over land. The fact that deeper cells are more likely over ocean does not contradict the advection hypothesis. As cells move offshore in the night and early morning, they mature and thus grow in vertical extent. However, there are also plenty of shallower cells over the ocean, suggesting that convection also initiates over the ocean itself. Over land, both sites exhibit an initial afternoon peak in IMERG rainfall, followed by a slight dip, then a second night-time peak. Machilipatnam also displays this feature in the fraction of cells. This suggests in the average situation that cells continue to initiate over land for a period of time, with a slight lull around 9 p.m. after the initial round of afternoon convection. After midnight, convection is hindered over land following large amounts of convection in the preceding hours, and so the diurnal cycle spreads out into the ocean (Yang \& Slingo, 2001).

For Mumbai, the most discernible change in the diurnal cycle is that the afternoon peak in the fraction of land cells and rainfall is not seen over ocean, which instead has a peak at night or early morning, similar to south-eastern India. This suggests that land surface heating over Mumbai, whilst smaller than the other locations, still has a significant contribution to convection. We note, however, that our Mumbai analysis is 


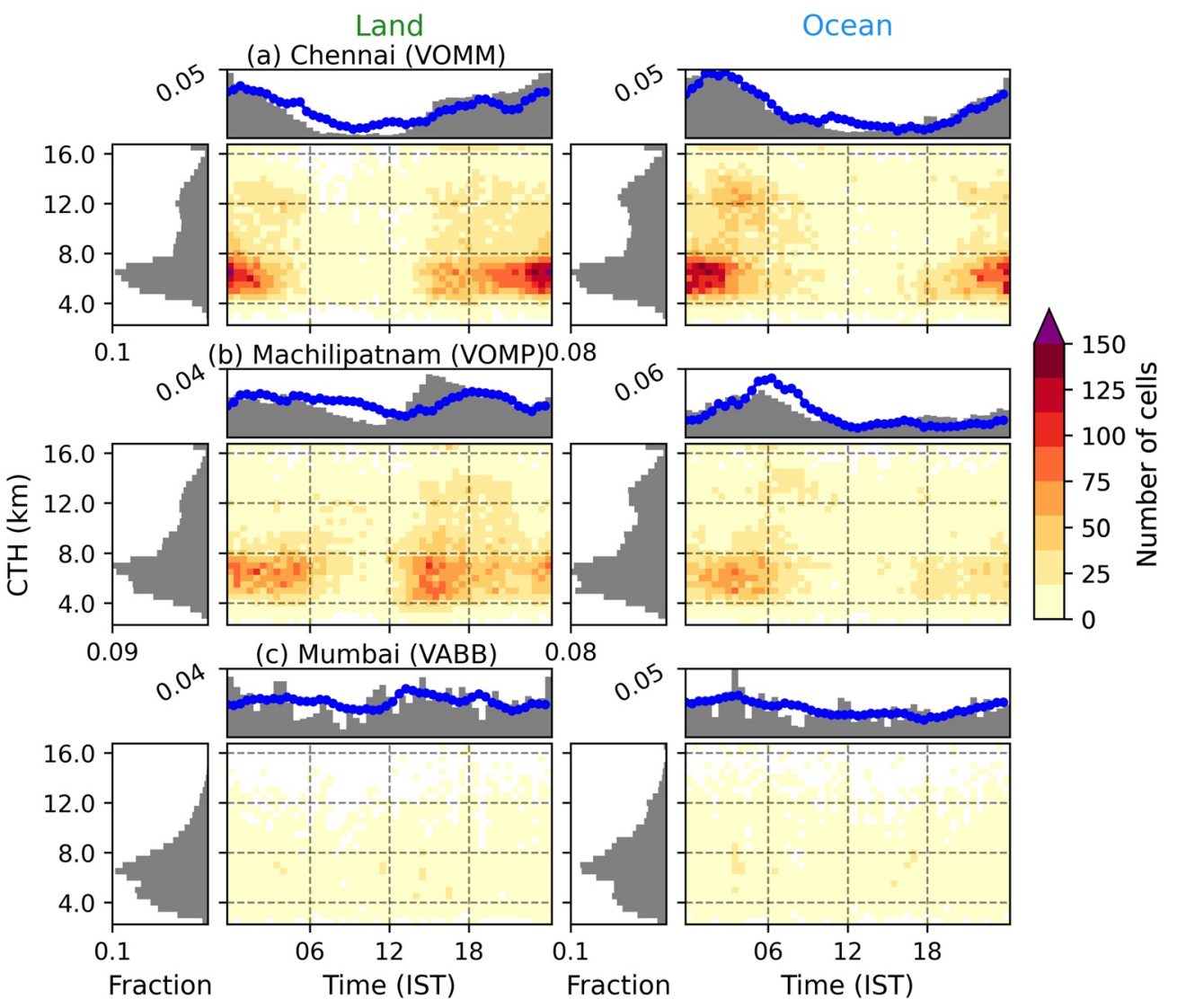

Figure 8. Same as Figure 6, but with separate plots for cells with their respective centroids over land and ocean. (a) Chennai, (b) Machilipatnam, and (c) Mumbai. A land-ocean mask is also applied to the IMERG rainfall.

biased toward the months of May and June with a small number of active period samples. However, the robustness of the interpretation of these results benefits from a similar number of radar volumes over the diurnal cycle (not shown). Also similarly to south-eastern India, Mumbai has a slightly higher fraction of deep cells over ocean compared to land, although this is not significant enough for a clear second peak in the CTH histogram. This may partly occur due to a smaller amount of collision-coalescence of raindrops over ocean away from the Western Ghat mountains, giving clouds a chance to grow more in vertical extent before precipitating out.

\subsection{Diurnal Cycle During Monsoon Progression}

The diurnal cycle can vary over longer time scales, such as the progression of the monsoon itself. The normalized diurnal cycle in cell number is shown for each month individually (May-September) in Figure 9. First, for all sites, the diurnal cycle is often least pronounced in May, as the monsoon regime is not yet established. Chennai shows a distinct night-time peak in the fraction of cells from June onwards. However, June also has the highest likelihood of convection in the hours around midday, with very few cells around this time later in the season. The length of this daytime period of relative inactivity extends into September, by which point convection is rare between 8 a.m. and 2 p.m. local time. As with Figure 6, Machilipatnam's diurnal cycle is more complex, exhibiting multiple peaks from June, most definitively one centered around 4 a.m. associated with ocean convection, and one around 4 p.m. for land convection. However, a third peak around midnight seems to occur in June and September, although this is not very distinct in IMERG rainfall. The minimum occurs around noon from July through September, and in fact these latter three months match considerably. This suggests the progression of the monsoon at this stage has less effect on the diurnal cycle of south-eastern India. 
(a) Chennai (VOMM)

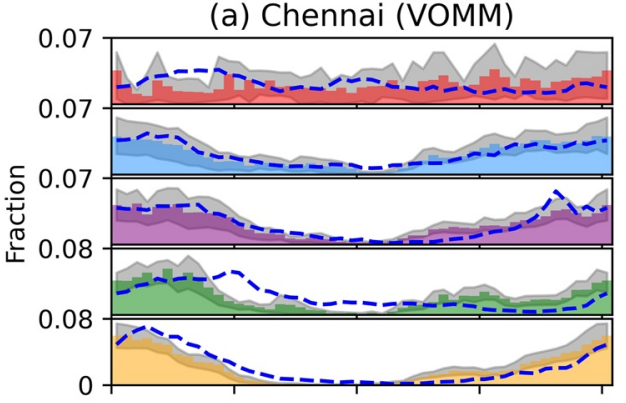

(c) Bhopal (VABP)

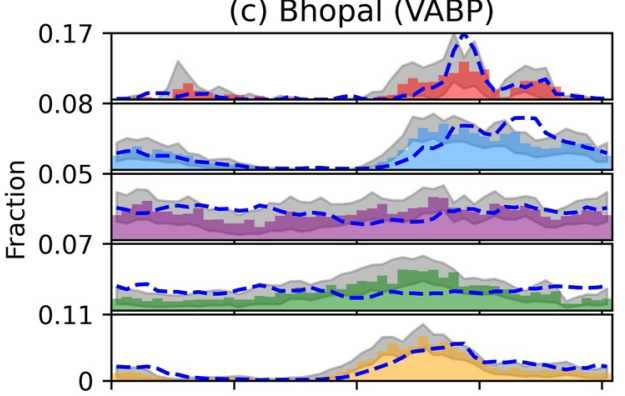

(e) Agartala (VEAT)

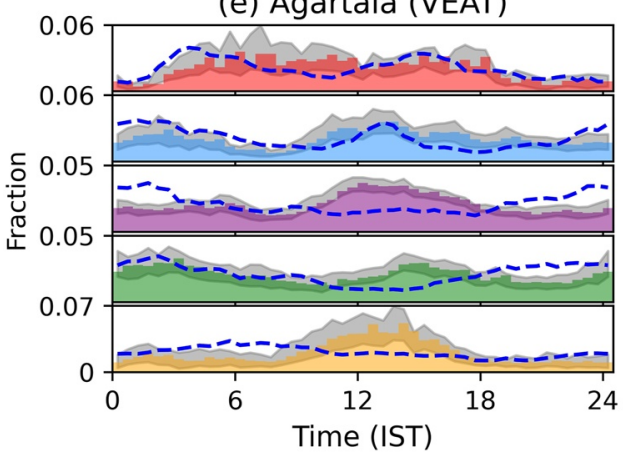

(b) Machilipatnam (VOMP)

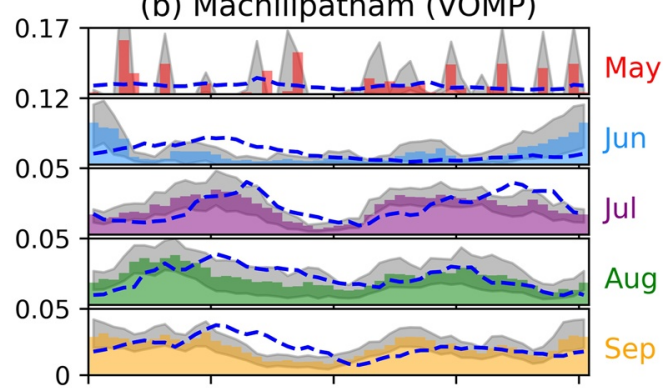

(d) Lucknow (VILK)

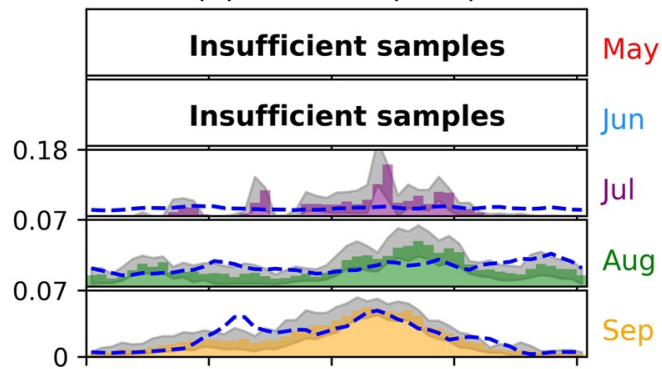

(f) Kolkata (VECC)

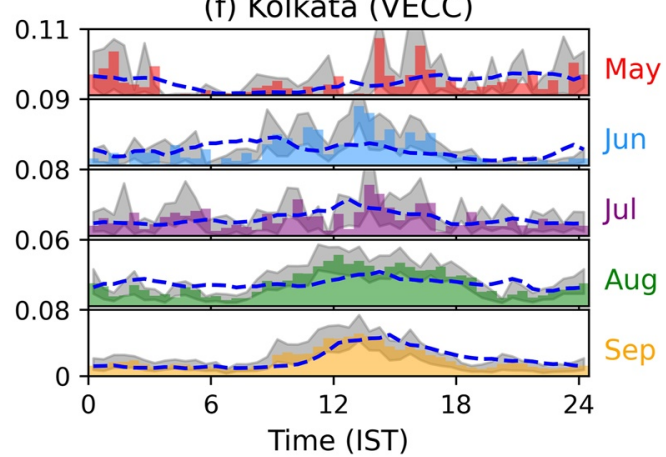

Figure 9. Diurnal cycle probability density histograms showing the number of convective cells subset by month for the same sites as in Figure 6, including cell-top height $>16 \mathrm{~km}$. However, Mumbai is not shown here due to long periods of unavailable data, especially during July and August. The shaded region represents the variance in the sample as the bootstrap 10th and 90th percentiles. The equivalent average IMERG rainfall diurnal cycle for each month is shown by the blue dashed line. There must be at least 500 cells during the month or the diurnal cycle is not shown.

Bhopal shows most clearly the arrival and retreat of the monsoon. In Bhopal and Lucknow the monsoon arrived on approximately June 20 (Ramesh, 2017). This is associated with a more pronounced diurnal cycle from June with a peak in the fraction of convection around 4 p.m. and extending into the evening and night. However, during peak monsoon months (July and August), convection can occur any time of day, demonstrated by a shallower peak in the afternoon, and in fact the diurnal cycle in IMERG rainfall becomes hard to visually decipher. This suggests a moister background environment more conducive for convection and less reliance upon daytime surface heating. Into September, as the monsoon gradually retreats south again, convection is once again constrained into the afternoon hours, especially for Bhopal. The development of convection from shallow to deep before precipitating out is pronounced in September (Figure S3a). Bhopal shows this effect most clearly, possibly as a result of its inland location as well as the tropospheric drying associated with monsoon withdrawal, resulting in a necessary period of shallow and congestus convection to moisten the environment in advance of any deep convection. Bhopal convection also seems to dissipate more quickly into the evening compared to June. This suggests a greater reliance upon surface heating for the initiation of convection. A longer convectively inactive period is visible from approximately 4 to $11 \mathrm{a} . \mathrm{m}$. for Bhopal in September. Lucknow displays comparatively more morning convection in September compared to Bhopal, with a minimum around midnight. 
Agartala shows a night-time and a day-time peak in convective fraction from June to August, with relative minima in between. We recall that the night-time peak in IMERG rainfall was found to stem from a higher proportion of deeper cells at night, with a tendency for cells during the day to be shallow and cumulus congestus type modes. The proportion of deep cells at night reduces into September, with all three convective modes then seeing their peak in the early afternoon (Figure S4). Kolkata has a peak in convective fraction centered around 2 p.m. for all months from June, but with convective cells and rainfall evident at all times of day, especially during June and July.

\subsection{Diurnal Cycle During Active and Break Periods}

It is also of interest to consider whether active and break spells may modulate the diurnal cycles shown earlier in this section, in terms of phase and/or amplitude. Figure 10 displays the phase of the diurnal cycles as in Figure 6, but now subsampled over the active and break days in Table 2. Chennai shows no clear change in the amplitude or phase of its diurnal cycle between active and break periods. Further, up the coast in Machilipatnam, however, there are clearly more inactive periods of convection during a break spell than an active spell, such as during late morning. In an active spell, convection can occur all times of day (although still preferentially during the afternoon and night-time). Figure S5 shows the cycles in Figure 10 for each individual cumulus mode. During active periods, deep cells are most common from 3 p.m. all the way through until around 7 a.m. as a single peak (Figure S5b). However, during break periods, these deep cells have a shallow peak at 4 p.m., followed by an evening lull, then a second, larger peak around midnight. Machilipatnam is systematically affected by active and break spells in this way, despite such a signal not being evident in the overall distribution of CTH in Figure 4. This suggests that cells in Machilipatnam that do occur are not on average less intense or deep during break periods, but are more dependent on the time of the day and thus less frequent, as shown in Table 4.

Turning our attention to northern India (Figures 10c and 10d), active periods display a higher fraction of convection during the night-time hours in Bhopal compared to break periods. Indeed, the diurnal maximum in the congestus mode during active periods is at night, whereas the peak in the deep mode is in the afternoon (Figure S5c). For Lucknow, break periods are associated with a higher fraction of cells in late evening and early morning, but active periods display a significantly higher fraction of late morning and afternoon convection. For both sites, there is a suggestion that the peak in normalized convection is slightly earlier in the afternoon for active periods, with more of an evening peak for break periods. This likely occurs as a result of the active spell environment being more conducive for convection, such that convection initiates, deepens and intensifies more quickly in the afternoon. This effect is also supported by the IMERG rainfall for Bhopal, although it is less clear for Lucknow.

Lastly observing the respective diurnal cycles for north-eastern India, it is evident that convection can occur at all times of day during both active and break periods. For Agartala, there is a more distinct peak in cell fraction in the early afternoon during break periods, with less of a diurnal cycle in active periods, and an almost constant proportion of IMERG rainfall through the day. Figures 10c-10e show large (weak) diurnal cycle amplitudes during break (active) periods. The lower relative humidity in these regions during break periods (Figure 5d) likely acts to constrain convection into the afternoon and evening hours, similarly to the September diurnal cycle in these regions. In contrast, during break periods, rainfall exhibits two peaks, one in the afternoon and a more significant one at night. For Kolkata, there is less of a visual difference on first inspection, however convection appears quicker to initiate around midday during active spells, and this peak is more well defined than the afternoon peak during break periods. The results in this section express the need for models to capture the interactions between large-scale regime changes (e.g., active/break periods and monsoon progression) and the local environment in different regions. In particular, the development of convection within the diurnal cycle is sensitive to background moisture associated with wind pattern changes in the lower troposphere, which models must resolve accurately to represent the diurnal cycle of convection. Field campaigns that prioritize high-resolution atmospheric observations, alongside longer periods of radar data availability, would in future allow the study of the diurnal cycle with relation to large-scale atmospheric conditions in more detail. 

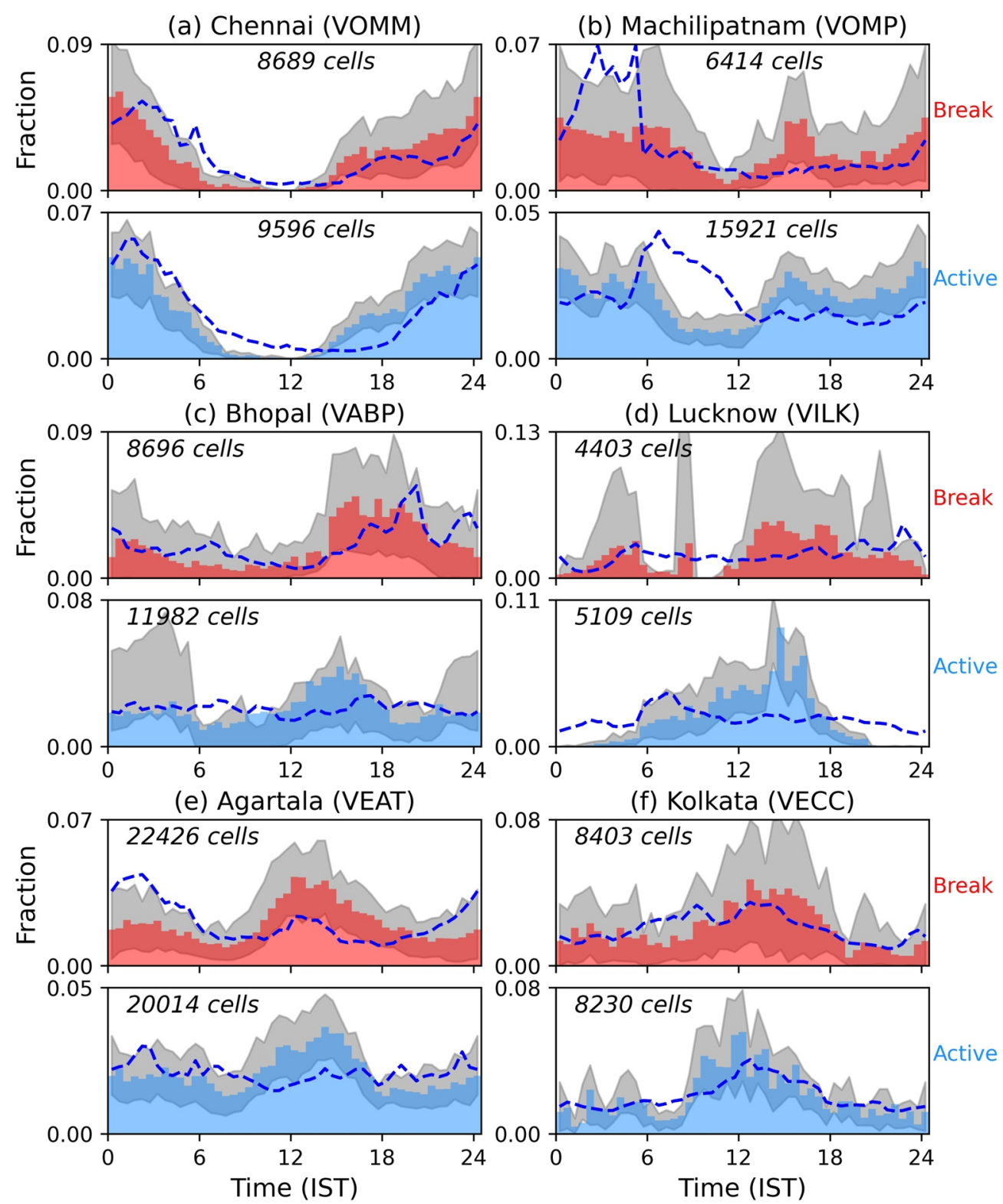

Figure 10. Same as Figure 9, but shown for break (red) and active (blue) periods. Mumbai is again not shown owing to a lack of radar volumes during the active and break spells during July and August. The total number of cells at a site over respective break and active spells is labeled to give the reader an idea of sample size. The right-most column in Table 4 shows the number of cells per radar volume to give a measure of average activity.

\section{Conclusions}

An understanding of ISM cloud development on large spatiotemporal scales is an important aspect of monsoon forecasting. This study has used 2016 monsoon season data from seven IMD Doppler radars in order to analyze CTH in relation to near-surface reflectivity, with a focus on active and break periods, the diurnal cycle, different months during the monsoon season, and location. Our main findings are as follows:

1. A season-average peak in CTH was found between 6 and $8 \mathrm{~km}$ for all sites, just above the freezing level and region of maximum tropospheric stability.

2. The seasonal distribution of CTH suggests the presence of three distinct convective cumulus modes: shallow convection, cumulus congestus, and deep convection. Considering the season as a whole, 
cumulus congestus is the dominant mode. $2 \mathrm{~km}$ reflectivity was found to increase rapidly with CTH below the melting layer, and slowly above it.

3. There is less convection per radar volume during break periods compared to active periods for all sites. CTH is also lower on average for the 2016 break periods for Bhopal and Mumbai, spatially matched with the positive rainfall anomalies. Other sites display no definitive change in the respective CTH distributions. Low-level wind circulation and $\theta_{\mathrm{e}}$ profile changes between active and break periods are an indicative driver of resultant variability in $\mathrm{CTH}$, most notably the position and strength of increased westerly winds associated with the position of the monsoon trough.

4. All sites but Mumbai show a clear seasonally averaged diurnal cycle in the number of cells, with differences between each climate region attributed to local and large-scale features of the atmosphere. The peak in rainfall tends to occur around or soon after the peak in the number of deep cells.

5. The phase of the diurnal cycle and average height of cells depends on the surface type being land or ocean for south-eastern India. Ocean cells exhibit more of an early morning peak in convection and have a higher proportion of deeper cells. Mumbai also shows more of an afternoon peak over land and an early morning peak over ocean, though the difference is more subtle.

6. The diurnal cycle is further modulated by the progression of the monsoon. During peak monsoon months (July and August), the diurnal cycle becomes less distinct for most sites, with longer spells of convective inactivity pre and post-monsoon. This is most definitive for northern India.

7. Active and break periods also modulate the diurnal cycle in rainfall and cell number for several sites. Break spells tend to see convection preferentially at the more convectively active times of day, whereas active spells are associated with convection through the day (but still more frequent at certain times).

This research naturally points toward further investigation of ISM monsoon clouds and their place in the large-scale monsoon circulation. An analysis of the vertical structure of convective cells (i.e., in terms of reflectivity) associated with different large-scale regimes would be a useful next step here. It would also be beneficial to expand aspects of this analysis to additional years if data were made available, especially regarding active and break periods which exhibit significant interannual variability. Similar analyses of the intricate relationship between cloud development and the wider monsoon circulation from a satellite or modeling standpoint could also further explore some of the patterns discussed here.

Our findings broadly agree with previous studies of multiple monsoon seasons using TRMM (e.g., Houze et al., 2007; Romatschke \& Houze, 2011; Romatschke et al., 2010; Shige \& Kummerow, 2016). Such agreement implies that the IMD weather radar data can successfully be used to study monsoon convection for individual years. The high temporal frequency and spatial resolution of the ground-based radars, as well as the planting of further radars since 2016 both in India (Roy et al., 2019), and recently Nepal (Talchabhadel et al., 2021), means they are valuable resources in the analysis of storm-scale and mesoscale phenomena for South Asia. The methodology presented here, including existing tools (e.g., Wradlib) developed using other radars (e.g., V. V. Kumar et al., 2013) should prove useful to study convection over India, especially allowing comparison across different radar sites.

Finally, these findings emphasize the potential use of these radar data for nowcasting and NWP case-study evaluation. Improvements in the representation of convection in NWP simulations of the monsoon will come from establishing what the biases are in the occurrence and morphology of different convective modes and evaluating the causes of these biases. This study provides a useful benchmark for model verification; the expansion of the radar network (Roy et al., 2019) and continued atmospheric sampling over time, will allow for deeper climatological questions to be investigated, such as the spatiotemporal variability of the convective modes. Furthermore, local capacity for model development-including at the Indian Institute for Tropical Meteorology and the National Center for Medium Range Weather Forecasting (e.g., Jayakumar et al., 2017; Martin et al., 2020) - will allow for continual model evaluation programs and development to occur. 


\section{Appendix A: Error Estimates for Echo-Top Heights}

The sampling strategy of operational weather radars leaves significant gaps, especially at higher elevation angles, which become greater as distance from the radar increases. For certain higher echo-top heights (ETHs) and at certain distances, the nearest India Meteorological Department (IMD) radar beam may be over- or undershooting the ETH by $2 \mathrm{~km}$ or more. Previous studies (e.g., Warren \& Protat, 2019) have already demonstrated the merits of vertical interpolation between beams to estimate features such as ETH. Lakshmanan et al. (2013) used model simulations to estimate the error in $18 \mathrm{dBZ}$ ETH and demonstrate that interpolation between beams provides an improved estimate compared to simply using the nearest beam. Jackson et al. (2018) evaluated ETH estimated from the C-band polarimetric radar against satellite-derived cloud top heights. While they find that the radar estimates are biased low, there is a statistically significant correlation between the two data sets that justifies the use of ETH for statistical analysis of convective storms over longer periods of time.

Here, we provide further evidence to justify the use of ETH derived from the IMD radars. There is no observational estimate for the "true" ETH during the 2016 ISM. For instance, the number of overpasses from the GPM core observatory is insufficient to carry out this analysis, which furthermore relies on a suitably large number of convective cells. Instead, we demonstrate the range-dependence of these errors using data from the Chilbolton Advanced Meteorological Radar (CAMRa) in the UK. CAMRa is a 0.28 $8^{\circ}$-beam S-band, dual-polarized Doppler radar. The narrow beam allows us to obtain an accurate estimate of the true ETH, with the beam width reaching $450 \mathrm{~m}$ at $100 \mathrm{~km}$ range from the radar (see Figure A1a, for an example). We use 2,975 range-height indicator (RHI) scans performed through convective storms in southern England from 10 days during 2011-2019.

To simulate the ETH retrieval as obtained using the IMD radars, we first smooth the CAMRa RHIs to the IMD radar beam width and then sample the smoothed RHIs at the IMD radar elevations (see Figure A1b). Next, we re-grid the sub-sampled and smoothed RHI to a regular Cartesian grid of $1 \mathrm{~km}$ by $0.5 \mathrm{~km}$, similar to the CAPPI reconstruction described in Section 2 (Figure A1c). Finally, ETH is determined at each $1 \mathrm{~km}$ in range as the height with reflectivity closest in value to $5 \mathrm{dBZ}$. Figure A1 shows the results for a single CAMRa scan, including ETH in panel d. Clearly, the instantaneous error can be quite large, reaching more than $2 \mathrm{~km}$ in this example. It is also evident that, the error depends strongly on where the radar beam is in relation to the true ETH, with errors closer to zero when the beam intersects the true ETH.

In Figure A2, we show the bias as a function of distance from the radar and estimated ETH for all ETH estimates in the 2,975 CAMRa RHI scans. Considering all ETH estimates, we find a statistically significant correlation between the true and estimated ETH of 0.93. The IMD radar scan strategy shows up very clearly in these statistics, as expected, with low bias where the radar beams intersect the true ETH. The bias is great-
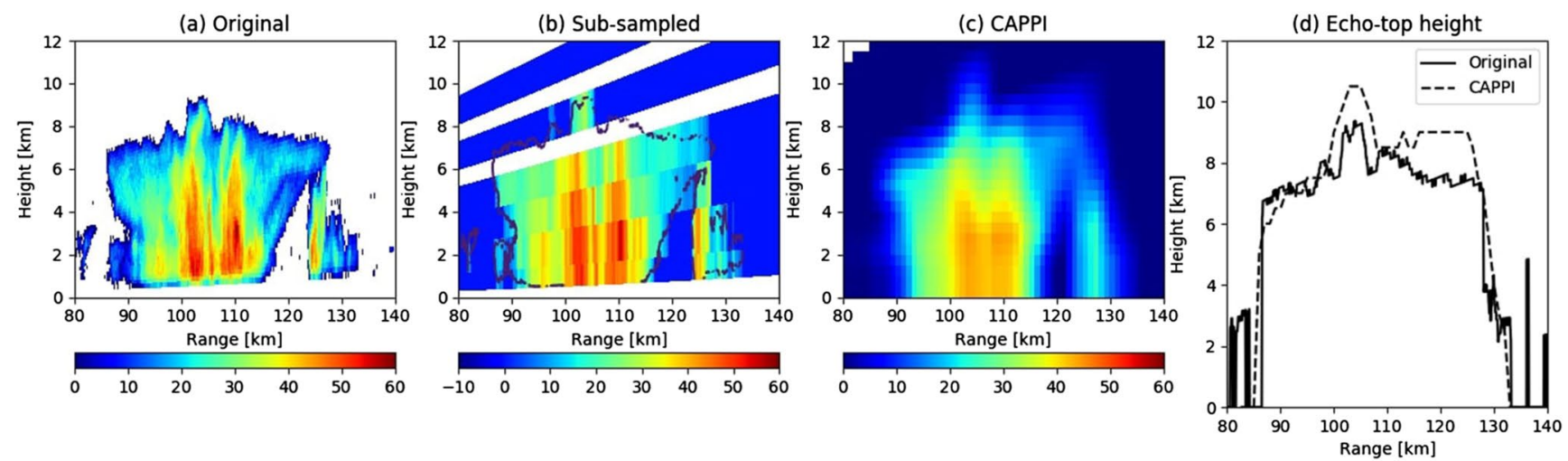

Figure A1. Example of simulating a Constant Altitude Plan Position Indicator (CAPPI) reconstruction from an range-height indicator (RHI) from the Chilbolton Advanced Meteorological Radar (CAMRa). (a) The original RHI scan from CAMRa. (b) The same data smoothed to $1^{\circ}$ in elevation and sub-sampled to the India Meteorological Department radar elevation angles. (c) CAPPI reconstructed from the data in panel (b) (d) Echo-top height estimated from the original RHI scan in panel (a) and the CAPPI in panel (c). 
er for those combinations of ETH and range where the beam separation is greater, although this might be exaggerated by the fact that ETH of $10 \mathrm{~km}$ and above were very rare in the CAMRa scans. To investigate the importance of beam separation further, we also simulate results using the CAMRa data but adopting a radar scan strategy with beam separation of $3^{\circ}$ starting from either $2^{\circ}$ or $1^{\circ}$. The resulting ETH from these simulations are shown in Figures A2b and A2c, respectively. The greater bias for combinations of ETH and range now also appear for ETH estimates below $9 \mathrm{~km}$, which were frequently observed in these data. However, if we ignore the range-dependence of these results, we note that the mean bias for ETH estimates below $9 \mathrm{~km}$ is close to zero for both strategies. The mean bias increases to $1 \mathrm{~km}$ for ETH estimates above $9 \mathrm{~km}$, but we postulate that this is due to the sparsity of true ETH above $9 \mathrm{~km}$ in the CAMRa data set.

This analysis demonstrates that the instantaneous errors in ETH estimation are generally of order $1 \mathrm{~km}$, which is comparable to the vertical grid resolution we consider for our CAPPIs. The results show that the errors are greatest where the radar beams are far removed from the true ETH, but for a given ETH estimate the spatial and temporal mean bias is expected to be close to zero. The mean bias is most relevant to the results presented in this study for multiple reasons. First, we consider ETH averaged over entire convective cells, that is, cell-top height (CTH). Second, these convective cells may propagate throughout the domain so that any remaining bias in $\mathrm{CTH}$ will vary depending on where the cell is located in terms of range to the radar. Finally, the statistics presented in this study are averaged over multiple days so that if cells may be assumed to be spread across the radar domains, the mean bias in ETH will be close to zero.

(a) Simulated IMD bias
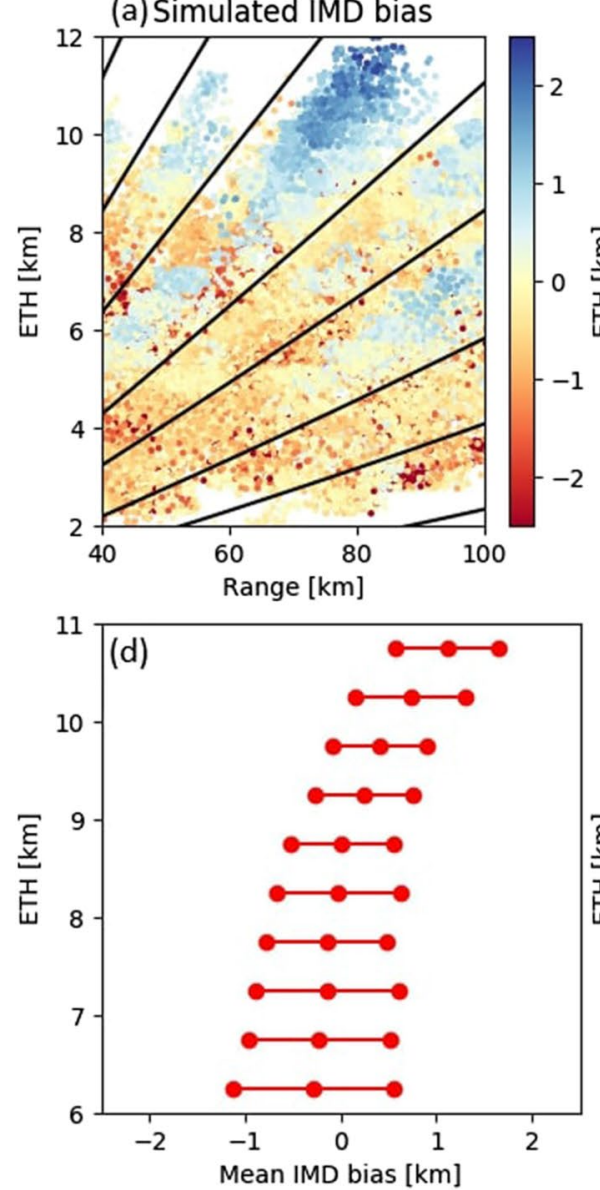

(b) 3-Deg 2-5-8 bias
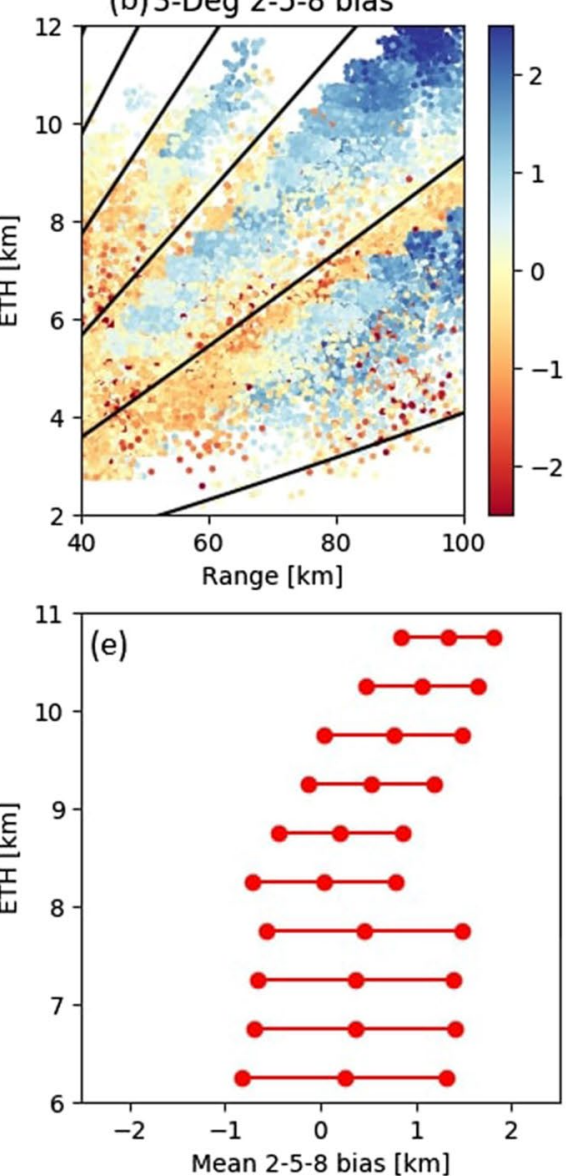

(c) 3-Deg 1-4-7 bias
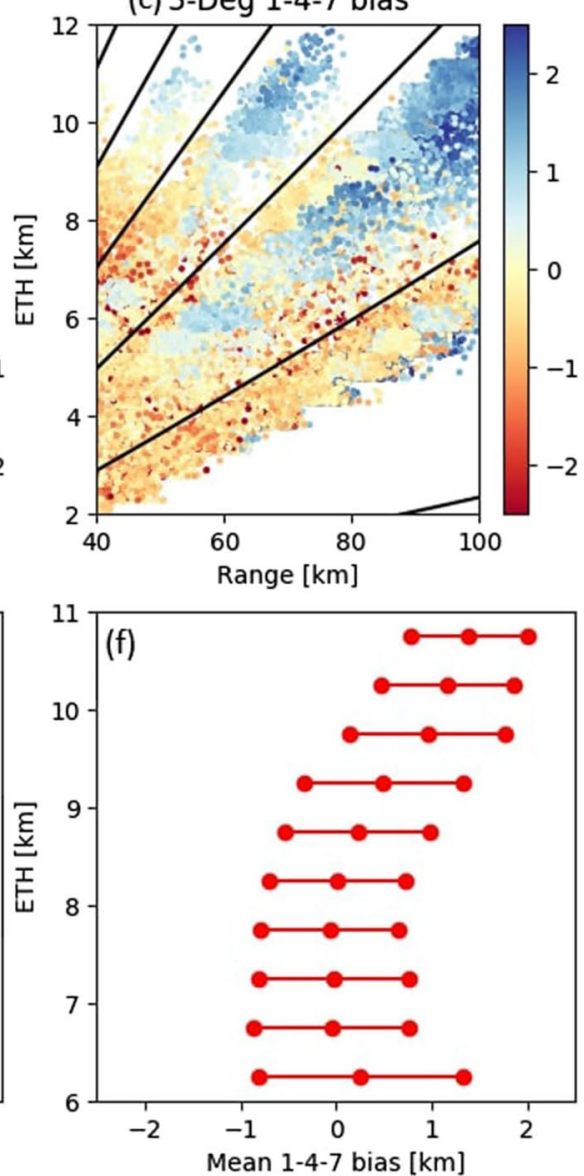

Figure A2. Mean bias in km for echo-top height (ETH) estimated by (a) simulating the India Meteorological Department radar scan strategy using CAMRa RHIs (b) simulating a scan strategy with beams separated by $3^{\circ}$ starting at $2^{\circ}$ and panel (c) as in panel (b), but starting at $1^{\circ}$. Scattered points are randomly placed around their specific ETH (within $0.25 \mathrm{~km}$ ) and range (within $0.5 \mathrm{~km}$ ). Lines show the central location of the radar beams considered. Panels (d-f) show the mean bias and standard deviation variation with height for each of the three strategies considering ranges between 40 and $100 \mathrm{~km}$, considering ETH between 6 and $11 \mathrm{~km}$. 


\section{Data Availability Statement}

CSV data of the convective cell statistics analyzed in this study are published at https://dx.doi.org/10.5285/ b28633ddc0f44d77a6aa81ad7bd66285. Atmospheric sounding data were provided by the University of Wyoming (http://weather.uwyo.edu/upperair/sounding.html). ERA5 data were downloaded from https://cds. climate.copernicus.eu/cdsapp\#!/dataset/reanalysis-era5-pressure-levels. GPM IMERG data were downloaded from https://gpm.nasa.gov/data/directory.

\section{Acknowledgments}

The authors thank the Editor, two anonymous reviewers, and Scott Collis for their helpful comments on improving an earlier version of this paper. The authors gratefully acknowledge the agreement of India's Ministry of Earth Sciences in providing the Doppler weather radar under the INCOMPASS project, funded in India under the Monsoon Mission. This work is supported by SCENARIO, grant number NE/ L002566/1.

\section{References}

Das, S. K., Konwar, M., Chakravarty, K., \& Deshpande, S. M. (2017). Raindrop size distribution of different cloud types over the Western Ghats using simultaneous measurements from Micro-Rain Radar and disdrometer. Atmospheric Research, 186, 72-82. https://doi. org/10.1016/j.atmosres.2016.11.003

Durai, V. R., \& Roy Bhowmik, S. K. (2014). Prediction of Indian summer monsoon in short to medium range time scale with high resolution global forecast system (GFS) T574 and T382. Climate Dynamics, 42, 1527-1551. https://doi.org/10.1007/s00382-013-1895-5

Harris, G. N., Jr, Bowman, K. P., \& Shin, D.-B. (2000). Comparison of freezing-level altitudes from the NCEP reanalysis with TRMM precipitation radar brightband data. Journal of Climate, 13, 4137-4148. https://doi.org/10.1175/1520-0442(2000)013<4137:COFLAF>2.0.CO;2

Heistermann, M., Jacobi, S., \& Pfaff, T. (2013). An open source library for processing weather radar data (wradlib). Hydrology and Earth System Sciences, 17, 863-871. https://doi.org/10.5194/hess-17-863-2013

Hersbach, H., Bell, B., Berrisford, P., Hirahara, S., Horányi, A., Muñoz-Sabater, J., et al. (2020). The ERA5 global reanalysis. Quarterly Journal of the Royal Meteorological Society, 146, 1999-2049. https://doi.org/10.1002/qj.3803

Houze, R. A., Wilton, D. C., \& Smull, B. F. (2007). Monsoon convection in the Himalayan region as seen by the TRMM Precipitation Radar. Quarterly Journal of the Royal Meteorological Society, 133, 1389-1411. https://doi.org/10.1002/qj.106

Huffman, G. J., Bolvin, D. T., Nelkin, E. J., \& Tan, J. (2020). Integrated Multi-satellitE Retrievals for GPM (IMERG) technical documentation. NASA. Retrieved from https://docserver.gesdisc.eosdis.nasa.gov/public/project/GPM/IMERG_doc.06.pdf

Jackson, R. C., Collis, S. M., Louf, V., Protat, A., \& Majewski, L. (2018). A 17 year climatology of the macrophysical properties of convection in Darwin. Atmospheric Chemistry and Physics, 18, 17687-17704. https://doi.org/10.5194/acp-18-17687-2018

Jayakumar, A., Sethunadh, J., Rakhi, R., Arulalan, T., Mohandas, S., Iyengar, G. R., \& Rajagopal, E. N. (2017). Behavior of predicted convective clouds and precipitation in the high-resolution Unified Model over the Indian summer monsoon region. Earth and Space Science, 4, 303-313. https://doi.org/10.1002/2016EA000242

Jiang, X., Li, T., \& Wang, B. (2004). Structures and mechanisms of the northward propagating boreal summer intraseasonal oscillation. Journal of Climate, 17, 1022-1039. https://doi.org/10.1175/1520-0442(2004)017<1022:SAMOTN>2.0.CO;2

Johnson, R. H., Ciesielski, P. E., \& Hart, K. A. (1996). Tropical inversions near the $0^{\circ} \mathrm{C}$ level. Journal of the Atmospheric Sciences, 53, 1838-1855. https://doi.org/10.1175/1520-0469(1996)053<1838:TINTL >2.0.CO;2

Krishnamurti, T. N., \& Bhalme, H. (1976). Oscillations of a monsoon system. Part I. Observational aspects. Journal of the Atmospheric Sciences, 33, 1937-1954. https://doi.org/10.1175/1520-0469(1976)033<1937:OOAMSP >2.0.CO;2

Kumar, S. (2017). A 10-year climatology of vertical properties of most active convective clouds over the Indian regions using TRMM PR. Theoretical and Applied Climatology, 127, 429-440. https://doi.org/10.1007/s00704-015-1641-5

Kumar, S., \& Bhat, G. S. (2017). Vertical structure of orographic precipitating clouds observed over south Asia during summer monsoon season. Journal of Earth System Science, 126, 114. https://doi.org/10.1007/s12040-017-0897-9

Kumar, V. V., Jakob, C., Protat, A., May, P. T., \& Davies, L. (2013). The four cumulus cloud modes and their progression during rainfall events: A C-band polarimetric radar perspective. Journal of Geophysical Research: Atmospheres, 118, 8375-8389. https://doi.org/10.1002/ jgrd.50640

Lakshmanan, V., Hondl, K., Potvin, C. K., \& Preignitz, D. (2013). An improved method for estimating radar echo-top height. Weather and Forecasting, 28, 481-488. https://doi.org/10.1175/WAF-D-12-00084.1

Louf, V., Protat, A., Warren, R. A., Collis, S. M., Wolff, D. B., Raunyiar, S., et al. (2019). An integrated approach to weather radar calibration and monitoring using ground clutter and satellite comparisons. Journal of Atmospheric and Oceanic Technology, 36, 17-39. https://doi. org/10.1175/JTECH-D-18-0007.1

Martin, G. M., Brooks, M. E., Johnson, B., Milton, S. F., Webster, S., Jayakumar, A., et al. (2020). Forecasting the monsoon on daily to seasonal time-scales in support of a field campaign. Quarterly Journal of the Royal Meteorological Society, 146, 2906-2927. https://doi. org/10.1002/qj.3620

Martin, G. M., Klingaman, N. P., \& Moise, A. F. (2017). Connecting spatial and temporal scales of tropical precipitation in observations and the MetUM-GA6. Geoscientific Model Development, 10, 105-126. https://doi.org/10.5194/gmd-10-105-2017

Martin, G. M., Milton, S. F., Senior, C. A., Brooks, M. E., Ineson, S., Reichler, T., \& Kim, J. (2010). Analysis and reduction of systematic errors through a seamless approach to modeling weather and climate. Journal of Climate, 23, 5933-5957. https://doi. org/10.1175/2010JCLI3541.1

May, P. T., \& Ballinger, A. (2007). The statistical characteristics of convective cells in a monsoon regime (Darwin, Northern Australia). Monthly Weather Review, 135, 82-92. https://doi.org/10.1175/MWR3273.1

Menon, A., Turner, A. G., Martin, G. M., \& MacLachlan, C. (2018). Modelling the moistening of the free troposphere during the northwestward progression of Indian monsoon onset. Quarterly Journal of the Royal Meteorological Society, 144, 1152-1168. https://doi.org/10.1002/qj.3281

Parker, D. J., Willetts, P., Birch, C., Turner, A. G., Marsham, J. H., Taylor, C. M., et al. (2016). The interaction of moist convection and mid-level dry air in the advance of the onset of the Indian monsoon. Quarterly Journal of the Royal Meteorological Society, 142, 22562272. https://doi.org/10.1002/qj.2815

Posselt, D. J., van den Heever, S. C., \& Stephens, G. L. (2008). Trimodal cloudiness and tropical stable layers in simulations of radiative convective equilibrium. Geophysical Research Letters, 35, L08802. https://doi.org/10.1029/2007GL033029

Qie, X., Wu, X., Yuan, T., Bian, J., \& Lu, D. (2014). Comprehensive pattern of deep convective systems over the Tibetan Plateau-South Asian monsoon region based on TRMM data. Journal of Climate, 27, 6612-6626. https://doi.org/10.1175/JCLI-D-14-00076.1 
Rajeevan, M., Bhate, J., Kale, J., \& Lal, B. (2006). High resolution daily gridded rainfall data for the Indian region: Analysis of break and active monsoon spells. Current Science, 91, 296-306.

Rajeevan, M., Gadgil, S., \& Bhate, J. (2010). Active and break spells of the Indian summer monsoon. Journal of Earth System Science, 119 , 229-247. https://doi.org/10.1007/s12040-010-0019-4

Ramesh, K. J. (2017). Annual report 2016. IMD. Retrieved from https://metnet.imd.gov.in/imdnews/ar2016.pdf

Rao, S. A., Goswami, B. N., Sahai, A. K., Rajagopal, E. N., Mukhopadhyay, P., Rajeevan, M., et al. (2019). Monsoon mission a targeted activity to improve monsoon prediction across scales. Bulletin of the American Meteorological Society, 100, 2509-2532. https://doi. org/10.1175/BAMS-D-17-0330.1

Rao, T. N., Saikranthi, K., Radhakrishna, B., \& Bhaskara Rao, S. V. (2016). Differences in the climatological characteristics of precipitation between active and break spells of the Indian summer monsoon. Journal of Climate, 29, 7797-7814. https://doi.org/10.1175/ JCLI-D-16-0028.1

Romatschke, U., \& Houze, R. A. (2011). Characteristics of precipitating convective systems in the South Asian monsoon. Journal of Hydrometeorology, 12, 3-26. https://doi.org/10.1175/2010JHM1289.1

Romatschke, U., Medina, S., \& Houze, R. A. (2010). Regional, seasonal, and diurnal variations of extreme convection in the South Asian region. Journal of Climate, 23, 419-439. https://doi.org/10.1175/2009JCLI3140.1

Roy Bhowmik, S. K., Sen Roy, S., Srivastava, K., Mukhopadhay, B., Thampi, S. B., Reddy, Y. K., et al. (2011). Processing of Indian Doppler Weather Radar data for mesoscale applications. Meteorology and Atmospheric Physics, 111, 133-147. https://doi.org/10.1007/ s00703-010-0120-x

Roy, S. S., Mohapatra, M., Tyagi, A., \& Roy Bhowmik, S. K. (2019). A review of Nowcasting of convective weather over the Indian region. MAUSAM, 70, 465-484.

Sathiyamoorthy, V., Pal, P., \& Joshi, P. (2004). Influence of the upper-tropospheric wind shear upon cloud radiative forcing in the Asian monsoon region. Journal of Climate, 17, 2725-2735. https://doi.org/10.1175/1520-0442(2004)017<2725:IOTUWS>2.0.CO;2

Shige, S., \& Kummerow, C. (2016). Precipitation-top heights of heavy orographic rainfall in the Asian monsoon region. Journal of the Atmospheric Sciences, 73, 3009-3024. https://doi.org/10.1175/JAS-D-15-0271.1

Sindhu, K. D., \& Bhat, G. S. (2018). Characteristics of monsoonal precipitating cloud systems over the Indian subcontinent derived from weather radar data. Quarterly Journal of the Royal Meteorological Society, 144, 1742-1760. https://doi.org/10.1002/qj.3328

Sindhu, K. D., \& Bhat, G. S. (2019). Storm characteristics and precipitation estimates of monsoonal clouds using C-band polarimetric radar over Northwest India. Theoretical and Applied Climatology, 138, 237-248. https://doi.org/10.1007/s00704-019-02828-6

Steiner, M., Houze, R. A., Jr, \& Yuter, S. E. (1995). Climatological characterization of three-dimensional storm structure from operational radar andraingaugedata.JournalofAppliedMeteorology,34,1978-2007.https://doi.org/10.1175/1520-0450(1995)034<1978:CCOTDS>2.0.CO;2

Talchabhadel, R., Ghimire, G. R., Sharma, S., Dahal, P., Panthi, J., Baniya, R., et al. (2021). Weather radar in Nepal: Opportunities and challenges in a mountainous region. Weather, 99. https://doi.org/10.1002/wea.3994

Testud, J., Bouar, E. L., Obligis, E., \& Ali-Mehenni, M. (2000). The rain profiling algorithm applied to polarimetric weather radar. Journal of Atmospheric and Oceanic Technology, 17, 332-356. https://doi.org/10.1175/1520-0426(2000)017<0332:TRPAAT>2.0.CO;2

Turner, A. G., Bhat, G. S., Martin, G. M., Parker, D. J., Taylor, C. M., Mitra, A. K., et al. (2020). Interaction of convective organization with monsoon precipitation, atmosphere, surface and sea: The 2016 INCOMPASS field campaign in India. Quarterly Journal of the Royal Meteorological Society, 146, 2828-2852. https://doi.org/10.1002/qj.3633

Turner, A. G., Sperber, K. R., Slingo, J., Meehl, G., Mechoso, C. R., Kimoto, M., \& Giannini, A. (2011). Modelling monsoons: Understanding and predicting current and future behaviour. In The global monsoon system: Research and forecast (2nd ed., pp. 421-454). World Scientific Series on Asia-Pacific Weather and Climate. https://doi.org/10.1142/9789814343411_0025

Utsav, B., Deshpande, S. M., Das, S. K., \& Pandithurai, G. (2017). Statistical characteristics of convective clouds over the Western Ghats derived from weather radar observations. Journal of Geophysical Research: Atmospheres, 122, 10056-10076. https://doi. org/10.1002/2016JD026183

Utsav, B., Deshpande, S. M., Das, S. K., Pandithurai, G., \& Niyogi, D. (2019). Observed vertical structure of convection during dry and wet summer monsoon epochs over the Western Ghats. Journal of Geophysical Research: Atmospheres, 124, 1352-1369. https://doi. org/10.1029/2018JD028960

Volonté, A., Turner, A., \& Menon, A. (2020). Airmass analysis of the processes driving the progression of the Indian summer monsoon. Quarterly Journal of the Royal Meteorological Society, 146, 2949-2980. https://doi.org/10.1002/qj.3700

Warren, R. A., \& Protat, A. (2019). Should interpolation of radar reflectivity be performed in Z or dBZ? Journal of Atmospheric and Oceanic Technology, 36, 1143-1156. https://doi.org/10.1175/JTECH-D-18-0183.1

Warren, R. A., Protat, A., Siems, S. T., Ramsay, H. A., Louf, V., Manton, M. J., \& Kane, T. A. (2018). Calibrating ground-based radars against TRMM and GPM. Journal of Atmospheric and Oceanic Technology, 35, 323-346. https://doi.org/10.1175/JTECH-D-17-0128.1

Willetts, P. D., Marsham, J. H., Birch, C. E., Parker, D. J., Webster, S., \& Petch, J. (2017). Moist convection and its upscale effects in simulations of the Indian monsoon with explicit and parametrized convection. Quarterly Journal of the Royal Meteorological Society, 143, 1073-1085. https://doi.org/10.1002/qj.2991

Yang, G.-Y., \& Slingo, J. (2001). The diurnal cycle in the tropics. Monthly Weather Review, 129, 784-801. https://doi. org/10.1175/1520-0493(2001)129<0784:TDCITT $>2.0$. CO;2 